\title{
The Motion in Limine in Politically Sensitive Cases: Silencing the Defendant at Trial
}

\author{
Douglas L. Colbert*
}

Until recently, in the interest of protecting defendants' rights, the judiciary has carefully circumscribed the use of the motion in limine ${ }^{1}$ in criminal cases. Specifically, trial judges limited the motion to preclusion of a specific, individual item of prejudicial evidence, and disallowed the exclusion of whole theories or defenses. Although this policy was initially developed in civil cases, ${ }^{2}$ the first judges to consider such motions in criminal cases also restricted the scope of the motion in

* Assistant Professor of Law, Hofstra University. B.A., State University of New York, Buffalo, 1968; J.D., Rutgers Law School, 1972. My thanks for the assistance and contribution of Suzanne Sangree.

1. Black's Law Dictionary defines "motion in limine" as "[a] written motion which is usually made before or after the beginning of a jury trial for a protective order against prejudicial questions and statements." BLACK's LAW Dictionary 914 (rev. 5th ed. 1979). Other dictionaries define "in limine" as being derived from the Latin word "limen," meaning threshold, Cassell's Latin Dictionary 319 (1957), or "at first inception, at first opportunity," ANDERSON's DictionaRY OF LAW 530 (1983).

The motion in limine is also used to avoid prejudicial questions or evidence from being heard by a jury and is most commonly made before trial, although a judge may defer a final, absolute order until the matter is actually raised at trial. In the latter case, the trial court issues a preliminary order prohibiting either party from referring to the subject matter in the jury's presence until the court makes its final ruling. Commentators prefer this "prohibitivepermissive" order to the "prohibitive-absolute" in limine ruling because it allows the judge to rule upon the admissibility of an evidentiary item after he becomes more familiar with the issues in the case. See Baca, Civil Procedure-New Mexico's Recognition of the Motion in Limine, 8 N.M.L. Rev. 211, 216 (1978) (student author); Fetscher, The Motion in Limine-A Useful Procedural Device, 35 Monr. L. Rev. 362, 368 (1974) (student author); Gamble, The Motion in Limine: A Pretrial Procedure That Has Come of Age, 33 ALA. L. Rev. 1, 12-13 (1981); Hyde, The Motion in Limine: Pretrial Trump Card in Civil Litigation, 27 U. FLA. L. REv. 531 (1975) (student author); Lafferty, Motion in Limine, 29 ARK. L. REv. 215, 223 (1975) (student author); Lerner, The Motion in Limine: A Useful Trial Tool, 4 Trial Dipl. J. 14 (Spring 1981); Love, Pretrial Exclusionary Evidence Rulings, 1967 Wis. L. REv. 738 (student author); Richardson, Use of Motions in Limine in Civil Proceedings, 45 Mo. L. REv. 130, 134 (1980) (student author); Rodin, The Motion in Limine: Uses and Abuses, 65 CHI. B. Rec. 230, 231 (1984); Rothblatt \& Leroy, The Motion in Liminie [sic] in Criminal Trials: A Technique for the Pretrial Exclusion of Prejudicial Evidence, $60 \mathrm{Ky}$. L.J. 611,616 (1972).

2. See Libco Corp. v. Dusek, No. 77-C-4386 (N.D. Ill. Apr. 29, 1986); Reidelberger v. Highland Body Shop, Inc., 83 Ill. 2d 545, 416 N.E.2d 268 (1981); Duffy v. Midlothian Country Club, 135 Ill. App. 3d 429, 481 N.E.2d 1037 (1985); Bradley v. Caterpillar Tractor Co., 75 Ill. App. 3d 890, 394 N.E.2d 825 (1979); Lewis v. Buena Vista Mut. Ins. Ass'n, 183 N.W.2d 198 (Iowa 1971); Schlagel v. Sokota Hybrid Producers, 279 N.W.2d 431 (S.D. 1979). 
limine. ${ }^{3}$

Recent cases, however, suggest an alarming trend. Government prosecutors are seeking to extend the common usage of the motion in limine in criminal trials in a way that seriously imperils defendants' rights. ${ }^{4}$ Prosecutors have begun filing broad pretrial motions in limine to prevent entire defenses from ever being heard, much less considered, by a jury. These motions are appearing more commonly in politically sensitive trials, where the accused's criminal charges derive from conduct that challenges or opposes established government policy. ${ }^{5}$ In this highly unorthodox use of the motion, prosecutors are asking trial courts to rule upon the appropriateness of an anticipated defense before the trial even begins and before the government has presented any witness testimony, much less sustained its burden of proof. ${ }^{6}$

Depending on how the court responds to the government's motion, the accused may face a highly undesirable choice: either respond to the government's motion or risk waiving a possible defense. If the court requires the defense to respond to the merits of the government's motion in limine, the court's action significantly compromises several of the accused's rights: the right against self-incrimination, ${ }^{7}$ the right to remain silent, ${ }^{8}$ and the right to be presumed innocent. ${ }^{9}$ Even when the court denies the motion, the government gains an enormous advantage in discovering the defense's trial strategy. ${ }^{10}$ Thus, the motion in limine, whether or not it is granted by the court, provides a unique opportunity for the government to discover and prepare to counter the specific defense or testimony that the defendant will present at trial. As a result, the government's responsibility and burden to prove guilt beyond a reasonable doubt is diminished.

Of greater import to the democratic scheme of our society is the case where the government's in limine motion succeeds. If the court grants the government's motion, the accused's right to present a full

3. People v. Brumfield, 72 Ill. App. 3d, 390 N.E.2d 589 (1979); State v. Quick, 226 Kan. 308, 597 P.2d 1108 (1979); State v. Bradley, 223 Kan. 710, 576 P.2d 647 (1978); Commonwealth v. Hood, 389 Mass. 581, 452 N.E.2d 188 (1983); State v. Brechon, 352 N.W.2d 745 (Minn. 1984).

4. See text accompanying notes 79-126 infra (trend in state courts); text accompanying notes 140-158 infra (trend in federal courts).

5. See text accompanying notes 102-160 infra.

6. In a criminal case, the government has the burden of proving guilt beyond a reasonable doubt; the accused has no burden, but may rely solely upon her presumption of innocence. See W. LaFave \& A. Scott, Criminal. Law § 1.4(a), at 17 n.8 (2d ed. 1986) (citing In re Winship, 397 U.S. 358 (1970)).

7. U.S. Const. amend. V.

8. Miranda v. Arizona, 384 U.S. 436 (1966).

9. See note 6 supra.

10. In a criminal case, the accused is not required to disclose his intended defense strategy prior to trial except when specifically required by statute. See, e.g., FED. R. CRIM. P. 12.1 (alibi), 12.2 (insanity). In the typical criminal trial, prosecutorial discovery is much more limited. The prosecutor may only discover documents and other tangible objects in the possession or control of the defense, or reports of certain examinations or tests. See FED. R. CRIM. P. 16(b)(1). 
and complete defense ${ }^{11}$ is placed in jeopardy, and the jury's role as a trier of fact ${ }^{12}$ is severely undermined. The Framers of the Constitution included the privilege of being tried by one's peers ${ }^{13}$ in the Bill of Rights because they knew that jury deliberation "was necessary to protect against unfounded criminal charges . ..."14 By vesting in the jury the power to determine the validity of government charges against a defendant, the framers made the citizenry a check on government abuse of its prosecutorial power.

While the use of the broad motion in limine jeopardizes an accused's right to a fair trial in every criminal case, this consequence is amplified when the defendant is known to oppose current government policy. Such politically sensitive trials ${ }^{15}$ are the severest test of the legal system's ability to protect the individual's right to a fair trial. The press, fueled by government press releases and leaks, often depicts the accused as one whose loyalty and patriotism is in doubt, and whose acts threaten the national security and legal order. Frequently, publicity surrounding trials of political dissidents will characterize defendants' beliefs as tantamount to advocating a violent overthrow of the present system. ${ }^{16}$ It is not unusual for defendants in such cases to encounter perceptions that they are dangerous lawbreakers, even before the government has presented any evidence at trial. Because of the prejudices at work in such trials, procedural fairness takes on added importance.

Political dissidents may have valid defenses to present in establishing that their acts were lawful and that they are victims of government abuse of its prosecutorial power. The single greatest guarantor of constitutional protection of individuals from government misuse of power is the right to trial by jury. ${ }^{17}$ In cases where the government has overstepped its legal bounds and violated individual rights, the jury has the

11. See, e.g., Crane v. Kentucky, 106 S. Ct. 2142, 2145 (1986) (citing California v. Trombetta, 467 U.S. 479, 485 (1984)); Washington v. Texas, 388 U.S. 14, 23 (1967); People v. Brumfield, 72 Ill. App. 3d 107, 112, 390 N.E.2d 589, 593 (1979); State v. Bradley, 223 Kan. 710,576 P.2d 647 (1978); State v. Brechon, 352 N.W.2d 745 (Minn. 1984).

12. See Sparf v. United States, 156 U.S. 51 (1895).

13. Source of Our Liberties 270, 288 (R. Perry ed. 1959).

14. Duncan v. Louisiana, 391 U.S. 145, 155-56 (1968).

15. The politically sensitive trial, as used in this article, is distinguished from the ordinary criminal case when the activities leading to the accused's arrest are based upon opposition to prevailing government policy, or when the individual charged is known and identified as a member of a group advocating such change.

16. Examples of the media's undue influence in politically sensitive trials are numerous. For an example of the media's role in jeopardizing an accused's right to a fair trial in a politically sensitive case in the 1960s and early 1970s, see Brady, Fair and Impartial Railroad: The Jury, the Media and Political Trials, 11 J. Crim. Just. 241, 252-58 (1983). Adverse media coverage also affected the outcome of trials against labor during World War I. See A. Bimba, The Molly McGuires (1932); M. Dubofsky, We Shall Be All (1969); W. Preston, Aliens and DISSENTERS (1963). In an account of one of the most highly publicized trials of this century, one author described how "under the pressure of hysterical and hostile press coverage ... the jury system collapsed because the charged atmosphere rendered the public unfit to deal with the issues." E. Morgan, The Legacy of Sacco and Vanzetri 204-05 (1948).

17. U.S. CoNST. amend. VI. 
ability to stay the hand of prosecutorial might and hold the government accountable to the letter of the law. In this way, juries function as an additional check on the executive branch of government in our constitutional system of checks and balances.

Yet a government's motion in limine, when successful in eliminating an entire defense, seriously erodes (if not completely nullifies) the crucial role of the jury as judge of fact. An in limine ruling limits the admissible evidence and, consequently, the information the jury receives. Because of this possible result, the judiciary must carefully scrutinize the criminal procedures used by the government in politically sensitive trials to assure preservation of constitutional guarantees and respect for citizens' rights. Absent such judicial control and government accountability to the people through the jury, the danger exists that the government will run roughshod over democratic principles in its fervor to quell political dissent.

In this article, I argue that the motion in limine represents a direct attack on the accused's right to trial by jury. The motion in limine to exclude an entire defense first appeared just after juries had acquitted civil rights protestors, anti-war demonstrators, and black liberation activists in several highly publicized trials in the late 1960s and early 1970s. I suggest that the recent trend in the expansive use of the motion in limine is an attempt by the government to avoid sustaining similar legal defeats, which would undermine its credibility and cripple its ability to formulate and implement controversial policies. Through the use of the motion, the government thus seeks to prevent the courtroom from operating as a public forum for government critics or as a popular referendum on government policies.

Part I of this article describes the history, development, and intended use of the motion in limine. It documents the use of the motion by the defense and the prosecution in criminal cases to eliminate prejudicial items of evidence from jury consideration. Part II examines the recent trend in the government's use of the motion in limine in state and federal prosecutions to preclude entire defenses from both ordinary criminal trials and politically sensitive trials. Part III discusses several cases in which federal prosecutors have used the broad motion in limine to exclude entire defenses in politically sensitive cases involving defendants who oppose the current administration's nuclear, racial, and immigration policies. Part IV analyzes the motion in limine's effect on the accused's constitutional rights, with particular emphasis on how the motion limits the accused's right to trial by jury.

\section{Historical Development of the Motion in Limine}

The motion in limine can be used by either party to an action. Under this procedure, the moving party seeks an evidentiary ruling that precludes the opposing party from asking prejudicial questions or in- 
troducing prejudicial material in the presence of the jury. ${ }^{18}$ The in limine procedure occurs most frequently before the commencement of trial, although the motion may be made at any time during the proceeding when a party first becomes aware that her adversary intends to use inflammatory material. ${ }^{19}$ Because the motion is usually made before trial, it is rarely recorded in reported decisions. Consequently, it is difficult to document the historical development of in limine practice. Most commentators place the earliest reported decision in $1933,{ }^{20}$ although one writer recently discovered a 1926 case involving a motion in limine. ${ }^{21}$

\section{A. The Origins of the Motion in Limine in Civil Cases}

From the early 1800 s to the early 1900 s, the phrase "in limine" surfaced in a number of Supreme Court decisions. ${ }^{22}$-The modern-day version of the motion in limine first appeared in a reported case just after the end of the Civil War. In the 1867 Supreme Court case of Mississippi $v$. Johnson, ${ }^{23}$ the Attorney General moved to strike Mississippi's complaint, which argued that state sovereignty vested Mississippi with the right to resist federal military governance under the Reconstruction Act. ${ }^{24}$ While the Court dismissed the state's complaint because it lacked the "jurisdiction ... to enjoin the President in the performance of his official duties," 25 the case marked the first time that the motion in limine was employed in an attempt to prevent prejudicial material from interfering with the judicial factfinder's determination.

In 1926, a Texas court became the first state court to affirm the use of the motion in limine in a civil trial as a means to preclude crossexamination that was "calculated to create prejudice."26 A sister state, however, rejected the procedure in another civil case seven years later as "an unwarranted usurpation of judicial power and authority."27

18. See Bruder, Pretrial Motions in Texas Criminal Cases, 9 Hous. L. Rev. 641, 653 (1972); Dolan, Rule 403: The Prejudice Rule in Evidence, 49 S. CAz. L. Rev. 220, 256 (1976); Hyde, supra note 1, at 532; Love, supra note 1, at 738, 740,745; Rothblatt \& Leroy, supra note 1, at 613 , 618, 624; Traster, Prolecting Your Client with the Motion in Limine, 1978 TRIAL LAw. Guide 147, $151,165$.

19. See note 1 supra.

20. Bradford v. Birmingham Elec. Co., 227 Ala. 285, 149 So. 729 (1933).

21. See Hazel, The Motion in Limine: A Texas Proposal, 21 Hous. L. Rev. 919, 922, 933 (1984) (citing Fort Worth \& D.C. Ry. v. Westrup, 278 S.W. 490 (Tex. Civ. App. 1925), aff'd, 285 S.W. 1053 (Tex. Comm'n App. 1926)).

22. See, e.g., Corporation of New Orleans v. Winter, 14 U.S. 91, 94 (1816); Watson v. Sutherland, 72 U.S. 74, 79 (1867); Osborn v. Nicholson, 80 U.S. 654, 656 (1872); The Telephone Cases, 126 U.S. 1, 163 (1888); White v. Leovy, 174 U.S. 91,93 (1899); Schick v. United States, 195 U.S. 65, 88 (1904) (Harlan, J., dissenting); Southern Pac. Ry. v. United States, 200 U.S. 341,349 (1906).

23. 71 U.S. 475 (1867)

24. Reconstruction Act, ch. 153, 14 Stat. 428 (1867).

25. Johnson, 71 U.S. at 501.

26. Fort Worth \& D.C. Ry. v. Westrup, 278 S.W. 490, 492 (Tex. Civ. App. 1925), affd, 285 S.W. 1053 (Tex. Comm'n App. 1926).

27. Bradford v. Birmingham Elec. Co., 227 Ala. 285, 287, 149 So. 729, 730 (1933). 
During the next thirty years, the motion's reported use was limited to a handful of civil cases in Texas ${ }^{28}$ and to a smattering of criminal cases. ${ }^{29}$ Though the motion in limine was born and developed in Texas, ${ }^{30}$ use of the motion has spread, and is today accepted in almost every state $\mathrm{e}^{31}$ as a general civil litigation tool. ${ }^{32}$ Most commentators and civil court decisions acknowledge that trial courts possess the authority to grant motions in limine in civil cases as part of their inherent power to admit and exclude evidence and to take such precautions as are necessary to afford a fair trial to all parties. ${ }^{33}$

The motion's many advantages in preventing prejudicial evidence from interfering with a fair and impartial jury verdict in civil litigation are now widely recognized. Most commentators agree that a court's cautionary instructions are usually ineffective after a jury has heard inadmissable, irrelevant, or inflammatory evidence. ${ }^{34}$ The motion in

28. The first reported Texas appellate court decision involving a motion in limine after Westrup was not until 1949. In Ford v. Carpenter, 147 Tex. 447, 452, 216 S.W.2d 558, 560 (1949), the Texas Supreme Court recommended that the trial court instruct the parties about permissible areas of inquiry before the trial commences. Several other cases similarly endorsed the term motion in limine. See Roosth \& Genecov Prod. Co. v. White, 152 Tex. 619, 629, 262 S.W.2d 99, 104 (1953); Sisk v. Glens Falls Indem. Co., 310 S.W.2d 118, 120 (Tex. Civ. App. 1958); Montgomery v. Vinzant, 297 S.W.2d 350, 354-56 (Tex. Civ. App. 1956).

29. See, e.g., State v. Flett, 234 Or. 124, 380 P.2d 634 (1963); Padgett v. State, 364 S.W.2d 397 (Tex. Crim. App. 1963); Bills v. State, 168 Tex. Crim. 369, 327 S.W.2d 751 (1959); Johns v. State, 155 Tex. Crim. 503, 236 S.W.2d 820 (1951); Lacy v. State, 168 Tex. Crim. 220, 325 S.W.2d 392 (1959); State v. Morgan, 192 Wash. 425, 73 P.2d 745 (1937); State v. Smith, 189 Wash. 422, 65 P.2d 1075 (1937);

30. See Blumenkopf, The Motion in Limine: An Effective Procedural Device with No Material Downside Risk, 16 NEw ENG. L. REv. 171, 176 (1981); Fetscher, supra note 1, at 363; Hazel, supra note 21, at 921-22; Hyde, supra note 1, at 532; Lafferty, supra note 1, at 224. But see Rodin, supra note 1, at 230 (motion in limine born in Alabama but developed in Texas).

In a 1962 civil case, the Texas Supreme Court explicitly approved the in limine practice "to prevent the asking of prejudicial questions and the making of prejudicial statements in the presence of the jury with respect to matters which have no proper bearing on the issues in the case or on the rights of the parties to the suit." Bridges v. City of Richardson, 163 Tex. 292, 293, 354 S.W.2d 366, 367 (1962).

31. See Hazel, supra note 21, at 919 n.3 (motion in limine is recognized, although not codified, in 46 states, the federal courts, and Puerto Rico).

32. Blumenkopf, supra note 30, at 172; Fetscher, supra note 1, at 370; Howell, The Use of Motions in Limine in Civil Litigation, 1977 ARIz. ST. L.J. 443 (student author); 20 AM. JUR. TRIALs, Motion in Limine Practice § 10 (1973).

33. The motion in limine is neither codified in any state statute nor expressly authorized in the Federal Rules of Criminal or Civil Procedure. In a 1984 criminal case, the practice was approved for the first time by the United States Supreme Court in Luce v. United States, 469 U.S. 38, 41 n.4 (1984), as within a district court's inherent authority to manage the course of a trial. Before the Supreme Court ruling, commentators and state courts had recognized this general authority of a trial court. See, e.g., Good v. A.B. Chance Co., 39 Colo. App. 70, 75, 565 P.2d 217, 221 (1977); Burrus v. Silhavy, 155 Ind. App. 558, 564-65, 293 N.E.2d 794, 797 (1973); Proper v. Mowry, 90 N.M. 710, 714-15, 568 P.2d 236, 241 (Ct. App. 1977); Baca, supra note 1, at 215; Blumenkopf, supra note 30, at 174; Davis, The Motion in Limine-A Neglected Trial Technique, 5 Washburn L.J. 232 (1966); Epstein, Motions in Limine-A Primer, 8 Litigation 34, 35 (Spring 1982); Feltscher, supra note 1, at 362; Hyde, supra note 1, at 535; Kromzer, Advantages to Be Gained by Trial Motions for the Plaintiff, 6 S. TEx. L.J. 178, 179 (1962); Lafferty, supra note 1, at 220; Rodin, supra note 1, at 230; Rothblatt \& Leroy, supra note 1, at 614-15.

34. See Baca, supra note 1, at 211; Blumenkopf, supra note 30, at 173; Epstein, supra note 33, at 34-35; Hyde, supra note 1, at 536; Lafferty, supra note 1, at 215; Rothblatt \&. Leroy, supra 
limine reduces the likelihood that a jury will be irrevocably prejudiced by hearing such evidence. ${ }^{35}$ The motion has the additional advantage of allowing a court to make a deliberate decision while avoiding delays and jury inconvenience during trial. ${ }^{36}$

But as the motion in limine was popularized and used more creatively, judges and commentators united around one important admonition: The in limine procedure must be limited to specific, individual items of prejudicial evidence, and must not be so overly broad as to restrict an opposing party's presentation of its case. ${ }^{37}$

In 1971, in Lewis v. Buena Vista Mutual Insurance Association, ${ }^{38}$ the Iowa Supreme Court became the first court to address the "questionable use" and dangers of the motion in limine when its effect is to preclude a plaintiff who has a "thin case" or a defendant with "a tenuous defense" from trying to establish this claim before a jury. ${ }^{39}$ The Iowa court characterized the motion to preclude an entire defense as a "drastic one, preventing a party as it does from presenting his evidence in the usual way," 40 and cautioned that "[i]ts use should be exceptional rather than general." 41 The court noted that the motion in limine "is usually used to prohibit mention of some specific matter, such as an inflammatory piece of evidence," and "is not ordinarily employed to choke off an entire claim or defense." 42 The court warned that "care must be exercised to avoid indiscriminate application of [the motion in limine] lest parties be prevented from even trying to prove their contentions." 43 The court concluded with an admonition against future use of the broad motion in limine in its jurisdiction: "The motion should be used, if used at all, as a rifle and not as a shotgun, pointing out the objectionable material and showing why the material is inadmissible and prejudicial." 44 Since Lewis, other state and federal court decisions have reiterated the Iowa Supreme Court's cautionary language as

note 1, at 635; Spencer, The Motion in Limine: Pretrial Tool to Exclude Prejudicial Evidence, 56 ConN. B.J. 325, 338 (1982); Traster, supra note 18, at 147; Annotation, Modern Status of Rules as to Use of Motion in Limine or Similar Preliminary Motion to Secure Exclusion of Prejudicial Evidence or Reference to Prejudicial Matters, 63 A.L.R.3D 311, 313 (1975).

35. Baca, supra note 1, at 219; Carter, Motions in Limine in Washington, 9 GoNz. L. REv. 780, 780 (1984) (student author); Epstein, supra note 33, at 34; Hazel, supra note 21, at 919; Lafferty, supra note 1, at 216; Rodin, supra note 1, at 231; Rothblatt \& Leroy, supra note 1, at 624; Traster, supra note 18 , at 165 .

36. See Carter, supra note 35, at 783; Davis, supra note 33, at 233; Epstein, supra note 33, at 35; Gamble, supra note 1, at 9; Love, supra note 1, at 749; Richardson, supra note 1, at 133; Rothblatt \& Leroy, supra note 1, at 635.

37. See note 2 supra; see also Baca, supra note 1, at 216-17; Blumenkopf, supra note 30 , at 182; Epstein, supra note 33, at 34; Gamble, supra note 1, at 11; Lerner, supra note 1, at 15; Rodin, supra note 1, at 234, 238.

38. 183 N.W.2d 198 (Iowa 1971).

39. Id. at 200-01.

40. Id. at 201.

41. Id.

42. Id.

43. Id. at 200 .

44. Id. at 201. 
the guiding principle for judging the propriety of the motion in limine in civil cases. ${ }^{45}$

\section{B. Use of the Motion in Limine in Criminal Trials}

The principle articulated in Lewis is all the more important in criminal cases, where the potential impact of an overly broad motion on defendant's constitutional right to a fair trial and upon her ultimate freedom overshadows the motion's effect in civil cases. It is true that the proper use of the motion in limine in a criminal case may promote trial fairness by discouraging lawyers, particularly prosecutors, from trying to influence a jury's verdict by loading the record with inflammatory and prejudicial evidence. ${ }^{46}$ But if a court permits a broader motion in limine, and the accused is precluded from presenting a full defense, the motion becomes a weapon against the accused's constitutional rights.

Historically, however, prosecutorial abuse of the motion in limine did not pose a problem in criminal trials. Until the late 1960s, the motion in limine was reported in only a few criminal cases, where it was usually ill-received. During the 1960s, the Warren Court's landmark due process decisions ${ }^{47}$ set the stage for greater judicial acceptance of

45. See Libco Corp. v. Dusek, No. 77-C-4386 (N.D. Ill. Apr. 29, 1986); Reidelberger v. Highland Body Shop, Inc., 83 Ill. 2d 545, 416 N.E.2d 268 (1981); Duffy v. Midlothian Country Club, 135 Ill. App. 3d 429, 481 N.E.2d 1037 (1985); Bradley v. Caterpillar Tractor Co., 75 Ill. App. 3d 890, 394 N.E.2d 825 (1979).

46. Dolan, supra note 18, at 228, 235 n.62, 256. Rule 403 of the Federal Rules of Evidence provides for excluding evidence "if its probative value is substantially outweighed by the danger of unfair prejudice, confusion of the issues, or misleading the jury, or by considerations of undue delay, waste of time, or needless presentation of cumulative evidence." The phrase "unfair prejudice" has been defined as "an undue tendency to suggest decision on an improper basis, commonly, though not necessarily, an emotional one." FED. R. Evid. 403 advisory committee's note.

47. The Warren Court held that the constitutional rights of the accused, contained in the fourth, fifth, and sixth amendments, were incorporated within the due process clause of the fourteenth amendment and applicable to the states. See, e.g., Mapp v. Ohio, 367 U.S. 643 (1961) (search and seizure); Gideon v. Wainwright, 372 U.S. 335 (1963) (right to counsel); Miranda v. Arizona, 384 U.S. 436 (1966) (privilege against self-incrimination and right to counsel); United States v. Wade, 388 U.S. 218 (1967) (suggestive identification).

In order to ascertain whether the motion in limine was used by criminal practitioners after Mapp v. Ohio was decided, I spoke with the Honorable Allen L. Danielson, currently a member of the Iowa Court of Appeals, who was engaged in private practice in Iowa in 1963. I selected Iowa because its state court was the first to address the growing use of the motion in limine in civil cases and to attempt to establish guidelines for its proper application. See Lewis v. Buena Vista Mut. Ins. Ass'n, 183 N.W.2d 198 (Iowa 1971).

Judge Danielson stated that the motion in limine was frequently used by criminal defense attorneys in Iowa shortly after Mapp was decided "from about 1963-1969." He referred to the in limine practice as "a wonderful vehicle for the defense to eliminate prejudicial evidence before trial." Judge Danielson recalled the first time he used the motion in limine in a criminal case-to preclude the prosecution from referring to the fact that the complaining witness in a rape case had contracted venereal disease. Judge Danielson believed that Mapp sanctioned the use of this pretrial strategy, and thought he was the first lawyer to use the motion in limine in an Iowa criminal case. Although the trial judge wondered "what the hell is this" upon reviewing Judge Danielson's in limine moving papers, he ultimately granted the motion. Telephone interview with Judge Danielson, Iowa Court of Appeals (December 22, 1986). 
legal measures to safeguard the rights of the accused, opening the way for defense use of the motion.

\section{Initial rejection of the motion in criminal cases.}

In 1937, the Washington State Supreme Court issued the first two published appellate decisions reviewing defense use of the motion in limine. Each decision addressed the question of whether the defense could move in limine to preclude prejudicial cross examination by the prosecution concerning a specific evidentiary matter. In State v. Smith, ${ }^{48}$ the Washington court reversed the defendant's conviction because the prosecuting attorney had violated the trial judge's in limine order. Later that same year, the court held in State v. Morgan ${ }^{49}$ that the trial judge had not abused his discretion when he declined to require the prosecutor to disclose before trial whether he intended to question the accused about his prior arrest record.

Two subsequent state court decisions in 1951 and 1963 flatly rejected a defense attempt to expand the use of the motion in limine to bar the prosecution from introducing prejudicial evidence in its direct case. In Johns $v$. State, ${ }^{50}$ the Texas Court of Criminal Appeals affirmed the trial court's denial of the defense application for a pretrial ruling to prevent the prosecution from introducing evidence regarding similar criminal acts committed by the defendant. Instead, the trial court stated that it would rule upon the admissibility of such evidence when offered by the prosecution during trial.

The appellate court in Johns did not consider whether the accused's right to a fair trial would be prejudiced when a jury heard evidence concerning the defendant's prior crimes, nor whether such potential prejudice could be erased by a court's cautionary jury instruction. Instead, the court focused on the effect such a pretrial exclusion could have on the prosecution's ability to conduct its case: "[T] he State has the right to prove its case in any way it may see fit under proper rules and regulations, and an accused cannot be allowed to direct either the method or manner of such proof." 51 Texas appellate courts followed this judicial practice in subsequent decisions that rejected defense efforts to use the motion to preclude prosecution cross-examination regarding defendant's prior convictions, ${ }^{52}$ and to obtain pretrial rulings on the admissibility of evidence. ${ }^{53}$

48. 189 Wash. 422,65 P.2d 1075 (1937).

49. 192 Wash. 425,73 P.2d 745 (1937).

50. 155 Tex. Crim. 503, 236 S.W.2d 820 (1951).

51. Id. at 507, 236 S.W.2d at 822.

52. See, e.g., Arrington v. State, 164 Tex. Crim. 20, 296 S.W.2d 537 (1956) (nothing in Texas criminal procedure found to permit a preliminary motion to preclude prosecution cross-examination on defendant's prior conviction).

53. Padgett v. State, 364 S.W.2d 397 (Tex. Crim. App. 1963) (motions to suppress in advance of proof held not to exist in state criminal procedure); Bills v. State, $168 \mathrm{Tex}$. Crim. 369, 327 S.W.2d 751 (1959); Lacy v. State, 168 Tex. Crim. 220, 325 S.W.2d 392 (1959). 
In State v. Flett, ${ }^{54}$ the Oregon Supreme Court, like the Johns court, prohibited the use of the motion in limine by the defense in criminal trials when it affirmed a trial judge's denial of defendant's in limine application. The defense had sought to preclude the prosecution from introducing evidence of the accused's infidelity in its case-in-chief. The Oregon court viewed the defense motion in limine as an impermissible interference with the prosecution of the case, stating tersely: "We have found no authority ... which requires the court to submit to a dress rehearsal in which the defendant may explore the state's evidence ...."55

2. The 1960s: increased judicial acceptance of criminal defense motions in limine.

The state judiciary's reluctance to accept criminal defense motions in limine began to give way in the 1960s. During that decade, several Supreme Court decisions, rendered under the leadership of Chief Justice Earl Warren, protected the accused's right to a fair trial at the expense of the state's ability to prosecute. The Warren Court incorporated federal constitutional guarantees into the due process clause of the fourteenth amendment, requiring the states to uphold federal constitutional safeguards against unreasonable searches and seizures, ${ }^{56}$ involuntary confessions, ${ }^{57}$ and suggestive police identification procedures. ${ }^{58}$

In holding that the rights of an individual whose personal liberty was at stake outweighed the interests of the state in prosecuting alleged lawbreakers, the Warren Court injected new life into the constitutional protections provided by the Bill of Rights. The Court took special care to protect the accused's right to receive a fair trial, particularly the right to trial by an impartial jury, ${ }^{59}$ by preventing the introduction of unlawfully obtained evidence. As a result, the use of pretrial suppression hearings emerged, at which judges ruled on the admissibility of evidence that could potentially prejudice criminal defendants. These hearings freed the accused from government use of unlawfully seized evidence at trial, and reaffirmed the fundamental right to be judged fairly by a jury.

In this judicial atmosphere, the motion in limine became accepted as an additional mechanism to assure the accused's sixth and fourteenth amendment rights to a fair trial. Courts began to permit defense

54. 234 Or. 124, 380 P.2d 634 (1963).

55. Id. at 130,380 P.2d at 637 . But see People v. Ventimiglia, 52 N.Y.2d 350, 420 N.E.2d 59, 438 N.Y.S.2d 261 (1981) (New York Court of Appeals urged prosecutors to obtain court rulings before introducing potentially prejudicial evidence).

56. Mapp v. Ohio, 367 U.S. 643 (1961).

57. Miranda v. Arizona, 384 U.S. 436 (1966).

58. United States v. Wade, 388 U.S. 218 (1967).

59. Duncan v. Louisiana, 391 U.S.145 (1968). 
lawyers to use the motion in limine to ascertain and limit the scope of the prosecution's cross-examination of the accused concerning prior convictions or arrests. ${ }^{60}$ In many situations, an accused would opt not to testify on her own behalf because of the likelihood that a prosecutor's cross-examination would concentrate on her prior criminal record, rather than on any inconsistencies in her trial testimony. When a court allows the defense to preclude questioning concerning prior convictions, the accused is then free to testify, knowing that the jury will not consider her past conduct as evidence of guilt on the current charge. This, in turn, brings a crucial witness before the jury, assisting its factfinding mission in search of the truth.

Applauding this opening to defense use of the motion in limine, two commentators called for defense attorneys to use the motion more, limited only by "the inventiveness of counsel."61 They recognized that the motion could prevent the prosecutor from uttering any prejudicial questions or statements that would interfere with an accused's right to a fair and impartial jury trial. The defense bar, however, has had little success in persuading courts to extend the motion's applicability beyond the preclusion of cross examination concerning the accused's prior arrests or convictions. Courts have followed the Johns-Flett reasoning, denying other defense motions in limine because they regard these motions merely as defense attempts to hamper the state's presentation of its case. ${ }^{62}$

60. See Luck v. United States, 348 F.2d 763 (D.C. Cir. 1965). In Luck, the court stated that a "trial court is not required to allow impeachment by prior conviction every time a defendant takes the stand in his own defense." Id. at 768 (emphasis in original). Instead, Luck entrusted the decision to the trial court's discretion, based on such factors as "the extent to which it is more important to the search for truth in a particular case for the jury to hear the defendant's story than to know of a prior conviction." Id. at 769; see also United States v. Bagley, 772 F.2d 482 (9th Cir. 1985), cert. denied, 106 S. Ct. 1215 (1986); United States v. Palumbo, 401 F.2d 270 (2d Cir. 1968), cert. denied, 394 U.S. 947 (1969); Luck, 348 F.2d at 768 n.7 (it is "a more just, humane and expedient solution" to allow the accused "to tell his story without incurring the overwhelming prejudice likely to ensue from disclosing past convictions" (quoting C. MCCORMICK, EvidenCE § 43, at 94 (1954)). State courts have also applied the discretionary Luck motion. See, e.g., Commonwealth v. Nighelli, 13 Mass. App. Ct. 590, 435 N.E.2d 1058 (1982); State v. Bennett, 122 R.I. 276, 405 A.2d 1181 (1979); People v. Sandoval, 34 N.Y.2d 371, 314 N.E.2d 413, 357 N.Y.S.2d 849 (1974). But see State v. Hawthorne, 49 N.J. 130, 228 A.2d 682 (1967) (holding trial court had no discretion to exclude evidence of defendant's prior convictions). In Luce v. United States, 469 U.S. 38 (1984), the Supreme Court approved the in limine practice, but held that, should the motion be denied, the right to appeal is preserved only if the accused testifies at trial.

61. Rothblatt \& Leroy, supra note 1 , at 624 .

62. See People v. Van Riper, 127 IIl. App. 2d 394, 262 N.E.2d 141 (1970) (denying defense motion in limine to exclude evidence that defendant previously used or possessed narcotic drugs, and concerning his manner of appearance or dress at the time of the crime), cert. denied, 403 U.S. 918 (1971); State v. Reeves, 234 Kan. 250, 671 P.2d 553 (1983) (denying defense motion in limine to exclude testimony of prior alleged incidents between complainant and defendant); People v. Ventimiglia, 52 N.Y.2d 350, 420 N.E.2d 59, 438 N.Y.S.2d 261 (1981) (denying in limine motion to preclude state from using defendants' statements that they had a place for disposing of the bodies of murder victims).

Federal courts have also disfavored broad motions in limine by the defense. In United States v. Denton, 547 F. Supp. 16 (E.D. Tenn. 1982), the court denied the defendant's motion 
3. Origins of the prosecutorial use of motions in limine.

Although criminal in limine practice first emerged as a defense procedure to assure the accused of a fair trial, state and federal prosecutors also began to use the motion in limine to exclude prejudicial items of evidence in a variety of situations. In recent years, state prosecutors have successfully used the motion to prevent the defense from crossexamining a government witness concerning a pending indictment ${ }^{63}$ or prior conviction. ${ }^{64}$ Prosecution motions have also barred the defense from introducing evidence that the deceased had sexually assaulted the defendant's sisters and daughters, ${ }^{65}$ and from bringing testimony that the deceased had a prior criminal record, unless relevant to a proper self-defense claim. ${ }^{66}$ Prosecutors' in limine motions have also precluded the defense from mentioning that the defendant had passed a polygraph test, ${ }^{67}$ or had made a prior payment of restitution. ${ }^{68}$

Federal prosecutors have also begun to rely increasingly upon the motion in limine to exclude specific, individual items of evidence from being raised by the defense. Prosecution motions have prevented defense lawyers from cross-examining a government witness about a prior nonfelony conviction, ${ }^{69}$ a pending murder indictment, ${ }^{70}$ or his alleged criminal conduct. ${ }^{71}$ In addition, courts have granted federal prosecution motions in limine to preclude defense counsel from inquiring into a government agent's possible entrapment of other taxpayers in unrelated bribery cases, ${ }^{72}$ or an agent's possible knowledge of INS officials "planting" marijuana on innocent persons. ${ }^{73}$ Prosecutors have also successfully employed the motion to prevent defense disclosure of the

in limine to preclude evidence and testimony concerning conversations about "hot guns, jewelry or stolen guns." Id. at 17. In its pretrial ruling, the Denton court declared:

At this time, the court has no way of knowing (1) whether any or all of the aforementioned evidence will be offered at trial, (2) if so, for what purpose or purposes, (3) whether, if offered, some or all of such evidence might be admissible for one or more purposes, and (4) if admissible, whether its probative value might be outweighed by Id. at 17 .

its prejudicial effect.

63. Scarborough v. State, 171 Tex. Crim. 83, 344 S.W.2d 886 (1961).

64. State v. Brown, 6 Kan. App. 2d 556, 630 P.2d 731 (1981) (witness' prior conviction for arson was not a crime involving dishonesty).

65. Kaiser v. State, 673 P.2d 160 (Okla. Crim. App. 1983) (alleged misconduct was not connected in time with the homicide, nor was it a proper basis for a defense of justifiable homicide).

66. Garcia v. State, 454 S.W.2d 400 (Tex. Crim. App. 1970).

67. Robinson v. State, 309 N.E.2d 833 (Ind. Ct. App. 1974).

68. State v. Johnson, 183 N.W.2d 194 (Iowa 1971).

69. United States v. Gloria, 494 F.2d 477 (5th Cir.), cert. denied, 419 U.S. 995 (1974).

70. United States v. Morgan, 757 F.2d 1074 (10th Cir. 1985).

71. United States v, Hill, 550 F. Supp. 983. (E.D. Pa. 1982), cert. denied, 464 U.S. 1039 (1984).

72. United States v. Bocra, 623 F.2d 281 (3d Cir.) (probative value of cross-examination outweighed by risk of confusing the jury by collateral explanation), cert. denied, 449 U.S. 875 (1980).

73. United States v. Love, 599 F.2d 107 (5th Cir.), cert. denied, 444 U.S. 944 (1979). 
positive results of an accused's psychological stress evaluation tests. ${ }^{74}$ In fact, federal prosecutors' frequent and creative use of the motion in limine during the last four years suggests that it has become an accepted strategy in United States Attorneys' motion practice. ${ }^{75}$

On the other hand, federal and state prosecutors have used the motion in limine proactively to protect defendants' rights by seeking court rulings before introducing evidence ${ }^{76}$ or conducting cross examination 77 that might prejudice an accused's right to a fair trial. New York's highest court approved this practice and went so far as to recommend that prosecutors submit in limine motions whenever there is doubt regarding the admissibility of potentially prejudicial evidence. ${ }^{78}$ Used in this way, a prosecutor's motion in limine works both to promote the accused's due process rights and to avoid unnecessary retrials caused by government error.

In most cases, however, the recent trend in the government's use of the motion in limine works against defendants' trial rights. With increasing frequency, prosecutors' motions in limine seek to prevent an accused from presenting a defense and from testifying fully at trial. The next section of this article examines this trend.

\section{Recent Trend: Prosecutorial Attempts to Expand the MOTION IN LIMINE}

With the increasing judicial acceptance of the motion in limine as a prosecutorial procedure in many diverse situations, ${ }^{79}$ resourceful prosecutors have begun to test the outer limits of judicial receptivity by using the motion to exclude entire defenses they regard as unduly prejudicial and irrelevant to the charges against the accused. This prosecutorial trend is significant, for it requires the defense to reveal its developing trial strategy and divert its resources away from crucial pretrial preparation.

74. United States v. Traficant, 566 F. Supp. 1046 (N.D. Ohio 1983).

75. Part II discusses a recent trend in the motion in limine as federal prosecutors have increasingly attempted to exclude entire defenses. See text accompanying notes 79-158 infra.

Other cases in which the federal prosecutors have relied upon the motion in limine to exclude items of evidence include United States v. Mest, 789 F.2d 1069 (4th Cir.) (videotaped hypnotic session of defendant precluded from trial), cert. denied, $107 \mathrm{~S}$. Ct. 163 (1986); United States v. Curtis, 782 F.2d 593 (6th Cir. 1986) (precluding expert witness from testifying that the tax law involved in the case was unsettled and complex); United States v. Wyman, $576 \mathrm{~F}$. Supp. 670 (D. Neb. 1982) (barring defendant's tape recordings and written materials showing that accused disagreed with tax law or thought it was unconstitutional).

76. United States v. Falco, 727 F.2d 659 (7th Cir. 1984) (government motion in limine to permit introduction of evidence of defendant's prior theft convictions in direct case); United States v. Clifford, 543 F. Supp. 424 (W.D. Pa. 1982) (government sought to introduce documentary evidence in direct case).

77. United States v. Mitchell, 397 F. Supp. 184 (D.D.C. 1974) (government's motion in limine sought ruling regarding proper cross-examination of defendant's character witnesses regarding defendant's prior perjury conviction).

78. People v. Ventimiglia, 52 N.Y.2d 350, 420 N.E.2d 59, 438 N.Y.S.2d 261 (1981).

79. See text accompanying notes 63-78 supra. 
When state judiciaries have assessed prosecutorial efforts to broaden the motion in limine, their decisions generally echo the cautionary warnings issued in earlier state civil decisions. State courts have consistently voiced a concern that broad in limine rulings, which prevent entire defenses from being raised before a jury, undermine an accused's fundamental right to a fair trial in both the ordinary and the politically sensitive case. Federal courts, on the other hand, have rarely expressed concern for the accused's trial rights in their rulings on broad prosecutorial motions. ${ }^{80}$ In fact, the trend in federal courts is increasingly to grant such prosecution motions, thereby preventing juries from hearing evidence related to an anticipated defense, such as necessity, ${ }^{81}$ duress, ${ }^{82}$ and others. ${ }^{83}$ These two trends-prosecution use and federal court acceptance of broad in limine motions-combine to infringe significantly on an accused's rights at trial.

\section{A. State Courts}

State appellate courts in Kansas, Illinois, Massachusetts, and Minnesota, in both ordinary and politically sensitive cases, have expressed a clear concern for the fundamental rights of the accused when faced with a prosecutor's pretrial motion to exclude an entire defense. Their decisions reflect and restate the clear principle, set forth in earlier state civil cases like Lewis v. Buena Vista Mutual Insurance Association, ${ }^{84}$ that courts should reject prosecution attempts to extend the boundaries of the motion in limine when such an extension would prevent the accused from presenting her case.

The first reported state case addressing the broad prosecution motion in limine is typical of state courts' reluctance to expand the scope of the motion. In the 1978 case of State $v$. Bradley, ${ }^{85}$ the Kansas Supreme Court reversed a first-degree murder conviction because of an improperly granted prosecution motion. The trial court below had

80. See text accompanying notes $58-59$ supra.

81. United States v. Dorrell, 758 F.2d 427 (9th Cir. 1985); United States v. Seward, 687 F.2d 1270 (10th Cir. 1982), cert. denied, 459 U.S. 1147 (1983); see also United States v. Fox, No. CR-85-152-TVC-RMB (D. Ariz. Dec. 31, 1985); United States v. Aguilar, 756 F.2d 1418 (9th Cir. 1985); United States v. Cottier, 759 F.2d 760 (9th Cir. 1985); United States v. Best, 476 F. Supp. 34 (D. Colo. 1979).

82. United States v. Williams, 791 F.2d 1383 (9th Cir.), cert. denied sub nom. Sears v. United States, 107 S. Ct. 233 (1986); United States v. Contento-Pachon, 723 F.2d 691 (9th Cir. 1984); see also United States v. Peltier, 693 F.2d 96 (9th Cir. 1982); United States v. Shapiro, 669 F.2d 593 (9th Cir. 1982), cert. denied, 471 U.S. 1106 (1985).

83. United States v. Rosenberg, 806 F.2d 1169 (3d Cir. 1986) (specific words, phrases, or expressions relevant to a possible "frame" defense precluded); United States v. Martinez, 785 F.2d 663 (9th Cir. 1986) (evidence of lack of intent precluded); United States v. Cottier, 759 F.2d 760 (9th Cir. 1985) (defenses based on international law and necessity precluded); United States v. Aguilar, 756 F.2d 1418 (9th Cir. 1985) (government sought to exclude defenses based on international law, religious freedom, and lack of criminal intent).

84. 183 N.W.2d 198 (Iowa 1971). For an extended discussion of Lewis, see text accompanying notes $38-45$ supra.

85. 223 Kan. 710, 576 P.2d 647 (1978). 
granted the prosecution's motion in limine precluding the defense from offering any evidence that the deceased had previously been arrested for a shooting incident. In reversing defendant's conviction and remanding for a new trial, the state supreme court recognized that the in limine ruling violated the accused's "right to present his theory of self-defense," 86 which required that he refer to the prior shooting incident to establish the deceased's motive and intent for allegedly initiating the attack against him. To exclude this defense, the court said, would violate the accused's absolute right "to present his version of the events so that the jury may properly weigh the evidence and reach its verdict." 87

The following year, in State v. Quick, ${ }^{88}$ the same state court reviewed a trial court's in limine ruling that prohibited the accused from introducing evidence that another person had confessed to the crime for which he was now standing trial. The Kansas court acknowledged the growing use of the motion in limine in its jurisdiction and sought to establish clear guidelines for its use in criminal cases. The court emphasized that the motion should not be general, but must "pinpoint the [prejudicial] material or evidence to be protected against ... and the specific basis for exclusion or admission." 89 Finding that the trial court's order deprived the defendant of a fair trial, the court warned "against the overuse of the motion in limine."90 Applying the language of Lewis, ${ }^{91}$ the Kansas court reiterated: "[The] primary purpose of the motion in limine is to prevent prejudice during trial. ... It must not be used to choke off a valid defense in a criminal action."92

In the 1978 case of People $v$. Williams, ${ }^{93}$ an Illinois appellate court characterized an in limine order as so overbroad that it "prohibit[ed] the defendant from presenting any meaningful defense."94 In reversing the defendant's conviction, the court concluded that the prosecution's motion was so broad that it precluded "any meaningful opening statement by the defendant, any showing of a witness' bias, or any challenge to a witness' credibility ...., [or any] evidence ... concerning the arresting officer's preexisting racial prejudice or prejudice directed to-

86. Id. at $713,576 \mathrm{P} .2 \mathrm{~d}$ at 650 .

87. Id.

88. 226 Kan. 308, 597 P.2d 1108 (1979).

89. Id. at 312,597 P.2d at 1112 . The court emphasized that the motion must be aimed at a specific item of evidence: "We repeat, it is important for the motion to state the specific matter that the movant believes to be inadmissible and prejudicial." Id. The court also suggested that the in limine order be temporary, because "no one knows exactly what will turn up later during the trial." Id. Furthermore, "[i]t is possible that events during the trial, bearing directly on questions of relevance, may support a change in the protective order." Id.

90. Id.; see State v. Hackelman, No. 58-504, slip op. (Kan. Ct. App. May 22, 1986) (expressing concern with whether an in limine ruling prevented the defendant from presenting a defense, but ultimately upholding trial court's granting of motion).

91. I83 N.W.2d 198, 201 (Iowa 1971).

92. Quick, $226 \mathrm{Kan}$. at 311,597 P.2d at 1112.

93. 60 Ill. App. 3d 529, 377 N.E.2d 367 (1978).

94. Id. at 533,377 N.E. $2 \mathrm{~d}$ at 370 . 
ward the defendant."95

The following year, in People v. Brumfield, ${ }^{96}$ a second Illinois appellate court expanded the Williams court's analysis, warning that "a motion in limine should be used with caution, particularly in criminal cases." 97 The defendant in this case had sought to defend against the pending murder charges by claiming that his intoxicated condition had been involuntarily induced; but the trial court had granted a prosecutor's motion in limine that prevented the accused from referring to his intoxicated or drugged condition. Unable to present an intoxication defense, he was convicted. The appellate court found that involuntary intoxication constituted a proper affirmative defense and reversed the conviction. The court characterized the state's motion in limine as "a motion to strike an entire defense," 98 and warned that "granting such a motion and thereby preventing the defendant from presenting evidence on an available defense not only distorts the traditional application of motions in limine, but likewise raises serious constitutional questions relating to an accused's right to present a defense."99 The court explained that the government's expanded use of the motion in limine threatened the defendant's right to defend himself in a criminal trial:

When used in the manner of its application in this case, [the motion in limine] has the potential to deprive a criminal defendant of his day in court. That a defendant may have a tenuous defense is an insufficient justification for prohibiting him from trying to establish that defense. ... Whether the defendant will be able to substantiate his defense sufficiently to generate a jury question cannot be known until the evidence is in, but a defendant has the right to present his defense at trial. . . . Summary judgments are allowed on rare occasions in civil cases, but never in criminal cases. ${ }^{100}$

In reversing the defendant's conviction and ordering a new trial, the court in Brumfield concluded that "the trial court's order granting the state's motion in limine before the admission of any evidence deprived the defendant of his fundamental right to defend himself in a criminal trial." 101

State prosecutors have also attempted to use the motion in limine to

95. Id.

96. 72 Ill. App. 3d 107, 390 N.E.2d 589 (1979).

97. Id. at 113,390 N.E.2d at 593.

98. Id.

99. Id.

100. Id. at 113, 390 N.E.2d at 594; see also People v. Phillips, 95 Ill. App. 3d 1013, 420 N.E.2d 837 (1981) (reversing an in limine ruling that had prevented the defense from referring to the many times the complainant police officer had been suspended as part of a selfdefense claim to a charge of attempted murder); People v. Richardson, 48 Ill. App. 3d 307, 362 N.E.2d 1104 (1977) (holding that an in limine order, which prevented the defense from referring to a complaining witness' request to withdraw his complaint, deprived defendant of a possible defense and the right to impeach the complaining witness).

101. 72 Ill. App. 3d at 113, 390 N.E.2d at 594. 
bar a justification defense in politically sensitive cases in which the accused's violation of law results either from protest against existing government policy or from the need to escape life-threatening conditions in prison. These motions have logically met with the same judicial concern for defendants' rights as in ordinary criminal cases.

Defense attorneys have presented the duress defense in state trials to justify an accused's escape from prison. ${ }^{102}$ When so used, this defense often directly challenges the government's ability to protect the incarcerated, the conditions of imprisonment, and the legitimacy of the prison system generally. In 1980, the United States Supreme Court in United States v. Bailey 103 established strict requirements for the duress defense in a federal prison escape case in order to avoid "convert[ing] every trial ... . into a hearing on the current state of the federal penal system."104

Though federal courts regard Bailey as a license to grant prosecution motions in limine restricting use of the duress defense, ${ }^{105}$ a state

102. The states have divided on whether to allow a jury to consider a duress defense in prison escape cases. Some states permit the submission of the duress defense to the jury. See, e.g., People v. Lovercamp, 43 Cal. App. 3d 823, 118 Cal. Rptr. 110 (1974); People v. Unger, 66 Ill. 2d 333, 362 N.E.2d 319 (1977); Commonwealth v. O’Malley, 14 Mass. App. Ct. 314, 439 N.E.2d 832 (1982); People v. Mendoza, 108 Mich. App. 733, 310 N.W.2d 850 (1981); People v. Martin, 100 Mich. App. 447, 298 N.W.2d 900 (1980); State v. Baker, 598 S.W.2d 540 (Mo. Ct. App. 1980); State v. Esquibel, 91 N.M. 498, 576 P.2d 1129 (1978). Other states, however, have declined to instruct the jury on the duress defense. See, e.g., State v. Mulalley, 126 Ariz. 278, 614 P.2d 820 (1980); United States v. Stewart, 370 A.2d 1374 (D.C. 1977); People v. Brown, 68 A.D.2d 503, 417 N.Y.S.2d 966 (1979); Commonwealth v. Stanley, 265 Pa. Super. 194, 401 A.2d 1166 (1979).

103. 444 U.S. 394 (1980).

104. Id. at 417.

105. This is a questionable interpretation of Bailey, since the case did not involve a motion in limine, but reviewed whether a duress defense in a prison escape case should have been submitted to a jury after evidence had already been presented. The Supreme Court upheld the trial court's ruling against instructing the jury on the defense. Justice Rehnquist, writing for the Court, said: "In order to be entitled to an instruction on duress or necessity to the crime charged, an escapee must first offer evidence justifying his continued absence from custody as well as his initial departure ...." Id. at 412-13. Justice Rehnquist elaborated on this theme in a footnote accompanying the opinion:

[W] hen we say that in order to have the theory of duress or necessity as a defense submitted to the jury an escapee must "first" offer evidence justifying his continued absence from custody, we do not mean to impose a rigid mechanical formula on attorneys and district courts as to the order in which evidence supporting particular elements must be offered. The convenience of the jurors, the court and the witnesses may all be best served by receiving the testimony "out of order" in certain circumstances, subject to an avowal by counsel that such testimony will later be "tied in" by testimony supporting the other necessary elements of a particular affirmative defense.

Id. at 412 n.9.

Justice Rehnquist's clarification does not preclude an entire duress defense pretrial, but emphasizes that, before a jury can be instructed on such a defense, the accused must establish that he has made "a bona fide effort to surrender or return to custody as soon as the claimed duress or necessity has lost its coercive force." Id. at 415 . The difference between a court deciding not to charge a jury on a defense after hearing the actual trial testimony and precluding it prior to trial, appears all too obvious. Nevertheless, the Ninth Circuit has cited Bailey when approving the government's use of the pretrial motion in limine to prohibit a duress 
court that considered such a motion held that it violated the defendant's trial rights. In Commonwealth v. O'Malley, ${ }^{106}$ the Appeals Court of Massachusetts rejected the prosecution's use of a pretrial motion in limine to preclude a duress defense in a prison escape case, ${ }^{107}$ and reversed the trial judge's in limine order. ${ }^{108}$ The appellate court recognized the difficulty the defense has in establishing the elements necessary to "warrant a reasonable doubt whether [an] escape was jus-

defense absent a sufficient offer of proof by the defendant. See United States v. Williams, 791 F.2d 1383 (9th Cir. 1986); United States v. Contento-Pachon, 723 F.2d 691 (9th Cir. 1984); United States v. Peltier, 693 F.2d 96 (9th Cir. 1982); United States v. Shapiro, 669 F.2d 593 (9th Cir. 1982). But see Bailey, 444 U.S. at 428 (Blackmun, J., dissenting) (arguing that in prohibiting the duress defense, the "Court is deciding factual questions that should be presented to a jury.")

106. 14 Mass. App. Ct. 314, 439 N.E.2d 832 (1982).

107. Id. at 322,439 N.E.2d at 837 . The Massachusetts court referred to the defense as one of "necessity," although it is more properly characterized as a duress defense when used to justify an accused's escape from prison. In United States $v$. Bailey, Justice Rehnquist, writing for the majority, stated that "modern cases have tended to blur the distinction between duress and necessity." 444 U.S. at 409. The historical distinction was first made in the common law:

Duress was said to excuse criminal conduct where the actor was under an unlawful threat of imminent death or serious bodily injury, which threat caused the actor to engage in conduct violating the liberal terms of the criminal law. While the defense of duress covered the situation where the coercion had its source in actions of other human beings, the defense of necessity, or choice of evils, traditionally covered the situation where physical forces beyond the actor's control rendered illegal conduct the lesser of two evils. Thus, where A destroyed the dike because B threatened to kill him if he did not, A could argue that he acted under duress, whereas, if A destroyed the dike in order to protect more valuable property from flooding, A could claim a defense of necessity.

Id. at 410 (citing W. LaFave \& A. Scott, Handbook on Criminal Law § 28, at 374-84 (1972)).

The Court in Bailey did not state "the precise contours of whatever defenses of duress or necessity are available" in a prison escape case, but found one principle constant: "[I]f there was a reasonable, legal alternative to violating the law, a chance both to refuse to do the criminal act and also to avoid the threatened harm," the defense will fail. Id. (citing W. LAFAVE \& A. SCOTT, supra, at 379).

108. The Massachusetts court in O'Malley focused upon five elements established in Lovercamp v. California, 43 Cal. App. 3d 823, 831-32, 118 Cal. Rptr. 110, 115 (1974):

(1) The prisoner is faced with a specific threat of death, forcible sexual attack or substantial bodily injury in the immediate future;

(2) There is no time for a complaint to the authorities or there exists a history of futile complaints which make any result from such complaints illusory;

(3) There is no time or opportunity to go to the courts;

(4) There is no evidence of force or violence used toward prison personnel or other "innocent" persons in the escape; and

(5) The prisoner immediately reports to the proper authorities when he has attained a position of safety from the immediate threat. O'Malley, 14 Mass. App. Ct. at 319 n.6, 439 N.E.2d at 825 n.6.

The Massachusetts court did not follow the Supreme Court's ruling in Bailey, 444 U.S. at 394 , but ruled that a jury question was presented whether the defendant was faced with "a specific threat in the immediate future, if his complaint to authorities . . . [was] futile, or whether he immediately reported to the authorities." 14 Mass. App. Ct. at 319, 439 N.E.2d at 835-36. The state court viewed the evidence "in the light most favorable to the defendant." Id. at 320, 439 N.E.2d at 836. But cf. Williams v. State, 711 P.2d 116 (Okla. Crim. App. 1985) (granting government's motion in limine to exclude duress defense in a prosecution for escape on the ground that the offer of proof was insufficient under Oklahoma law). 
tified by necessity."109 Yet it criticized "the notion of [the prosecution] using a pretrial motion to test the adequacy of the entire defense case." 110 Citing language from Lewis v. Buena Vista Mutual Insurance Association"11 and State v. Quick,112 the court concluded that "neither counsel nor the judge should permit a criminal trial by jury to be converted into a trial by motion, with the possible effect of directing a verdict against the defendant."113 The O'Malley court advised that a trial judge should determine the legal sufficiency of a recognized defense only after having heard the trial testimony, and should include these rulings in the court's jury instructions. ${ }^{114}$

Prosecutors have also attempted to use the motion in limine in state courts to strike anticipated necessity defenses in situations where defendants have engaged in civil disobedience to protest government policy. In Commonwealth $v$. Hood, ${ }^{15}$ the highest Massachusetts appellate court endorsed the principles set forth in O'Malley, even though it affirmed a lower court's in limine ruling precluding defendant's use of the necessity ${ }^{16}$ defense at his trial for trespassing at a nuclear power

109. O'Malley, 14 Mass. App. Ct. at 319, 439 N.E.2d at 835 (quoting Commonwealth v. Thurber, 383 Mass. $328,331,418$ N.E.2d 1253, 1256 (1981)).

110. Id. at 323,439 N.E.2d at 837.

111. 183 N.W.2d 198 (Iowa 1971).

112. 226 Kan. 308, 577 P.2d 1108 (1979).

113. O'Malley, 14 Mass. App. Ct. at 325,439 N.E.2d at 838 .

114. The O'Malley court advised:

In the usual case ... it is far more prudent for the judge to follow the traditional, and constitutionally sounder, course of waiting until all the evidence has been introduced at trial before ruling on its sufficiency to raise a proffered defense. If, at that time, the defendant has failed to produce some evidence on each element of the defense, the judge should decline to instruct on it. In that event, the judge may, if appropriate, give curative instructions to caution the jury against considering evidence not properly before them.

Id. (Citations omitted).

115. 389 Mass. 581,452 N.E.2d 188 (1983).

116. Massachusetts courts have defined the defense of "necessity or competing harms" as follows:

In essence, the "competing harms" defense exonerates one who commits a crime under the "pressure of circumstances" if the harm that would have resulted from compliance with the law ... exceeds the harm actually resulting from the defendant's violation of the law. At its root is an appreciation that there may be circumstances where the value protected by the law is, as a matter of public policy, eclipsed by a superseding value ....

Commonwealth v. Brugmann, 13 Mass. App. Ct. 373, 376-77, 433 N.E.2d 457, 460 (1982), quoted in O'Malley, 389 Mass. at 590, 452 N.E.2d at 194.

State prosecutors' motions in limine have also been granted in three other reported decisions where the defendants' offers of proof were ruled insufficient as a matter of law. See State v. Linnehon, 454 So. 2d 625 (Fla. Dist. Ct. App. 1984) (proffered necessity defense was irrelevant and properly excluded from trial involving charges arising from nuclear protest demonstration); Commonwealth v. Brugmann, 13 Mass. App. Ct. 373, 433 N.E.2d 457 (1982) (granting the prosecution's pretrial ruling on the availability of defendant's "competing harms" defense, ruling that "other remedies were available to redress the present grievance"); State v. Olsen, 99 Wis. 2d 572, 299 N.W.2d 632 (Wis. Ct. App. 1980) (defendant was prevented from presenting a necessity defense because the court ruled, as a matter of law, that the defendant's actions were not caused by a natural physical force).

In other antinuclear protest cases, courts have permitted the defense to present evidence 
plant. The court based its affirmance upon the lack of prejudice in the trial judge's in limine order because the defense offer of proof was insufficient and failed to set forth the elements of the necessity defense. ${ }^{117}$ Nonetheless, the court recognized that the motion in limine is "typically directed at a specific item of evidence or testimony,"118 not an entire defense. Although it granted the prosecution's motion, the Hood court cautioned against the future use of such broad pretrial rulings: "We believe that ordinarily a judge should not allow a motion ... to exclude, in advance of it being offered, potential evidence of the defense."119 The Massachusetts high court suggested instead that trial courts rule upon government objections to any proposed defense at trial, and not in limine. ${ }^{120}$ In addition, a concurring justice warned that precluding an entire defense could undermine the jury's role in the criminal justice system. ${ }^{121}$ Thus, even though it allowed the prosecu-

during trial, but have ruled the evidence insufficient to instruct a jury on a proposed necessity defense. See State v. Marley, 54 Haw. 450, 509 P.2d 1095 (1973) (no direct causal relationship could reasonably be anticipated to exist between the defendant's action and the avoidance of harm); State v. Greene, 5 Kan. App. 2d 698, 623 P.2d 933 (1981) (nuclear power plant did not present the threat to life and health contemplated by the state "compulsion" statute to justify criminal actions to prevent its operation); State v. Kerr, 398 A.2d 384 (Me. 1979) (evidence was insufficient to raise a reasonable doubt as to whether there was imminent danger of physical harm to defendant or to plant workers); Commonwealth v. Averill, 12 Mass. App. Ct. 260, 423 N.E.2d 6 (1981) (defense failed to show the existence of an immediate danger or any reasonable expectation that the acts of trespass would have any "immediate consequences" in reducing such a danger); State v. Dorsey, 118 N.H. 844, 846, 395 N.E.2d 855, 855 (1978) (necessity defense, recognized by New Hampshire statute, was insufficient because it failed to "deal with nonimminent or debatable harms, [and] . . . with activities that the legislative branch of government expressly sanctioned and found not to be harms"); People v. Chachere, 104 Misc. 2d 521, 428 N.Y.S.2d 781 (N.Y. Dist. Ct. 1980) (defense did not establish that an emergency condition existed within defendant's knowledge, or that his action had a reasonable certainty of success); State v. Warshaw, 138 Vt. 22, 25, 410 A.2d 1000, 1002 (1979) (defense was held inapplicable on the ground that "the hazards are long term, [and] the danger is not imminent").

117. The Hood court applied the Brugmann court's analysis, stating:

"[T] $\mathrm{T}$ he application of the defense is limited to the following circumstances:

1. The defendant is faced with a clear and imminent danger, not one which is debatable or speculative;

2. The defendant can reasonably expect that his action will be effective as the direct cause of abating the danger; and

3. There is [no] legal alternative which will be effective in abating the danger;

4. The legislature has not acted to preclude the defense by a clear and deliberate choice regarding the values at issue."

389 Mass. at 581,452 N.E.2d at 195 (quoting Brugmann, 13 Mass. App. Ct. at 379, 433 N.E.2d at 461 , and W. LAFAVE \& A. Scotr, supra note 107, at 387-88).

The court concluded that the defendants' proof did not meet the first and third elements. "They could not have reasonably expected their actions to abate the alleged danger directly... . Nor did the defendants lack legal alternatives to abate the danger." Id. at 593, 452 N.E.2d at 196.

118. Id.

119. Id. at 595 n.5, 452 N.E.2d at 197 n.5.

120. Id. ("Since a judge is required to instruct on any hypothesis supported by the evidence, in most instances proffer of disputed matter at trial, ruled upon in the usual course, is more likely to be fair and result in correct rulings.")

121.That the defendants should be allowed to present their defense is required by a 
tion to exclude an entire defense, the Hood court expressed serious concern about the effect of its ruling on defendants' trial rights.

In the latest state court pronouncement on this subject, State $v$. Brechon, ${ }^{122}$ the Minnesota Supreme Court rejected the government's use of a motion in limine to exclude a necessity defense in a prosecution arising from a criminal trespass at a Honeywell munitions plant. The court denied the broad prosecutorial motion because it feared that granting such a motion would infringe on the accused's rights by facilitating the government's efforts to carry its burden of proof. ${ }^{123}$ The court also "disapprove[d] of so broad an exclusionary order as employed in this case ... because it raises serious constitutional questions relating to a defendant's right to testify."124 The court held that it is "fundamental that criminal defendants have a due process right to explain their conduct to a jury," 125 and suggested that the admissibility of the accused's testimony be decided by the trial court as the trial proceeds. In a concurring opinion, two justices urged trial courts to "scrutinize with the greatest care any restriction on a defendant's testimony offered .... as to his or her intent and the motivation underlying that intent lest we jeopardize the federal and state constitutional right to a fair trial." 126

\section{B. Federal Courts}

Several years before state prosecutors resorted to the broad motion in limine, federal prosecutors first attempted to extend the use of the motion in limine to preclude an entire defense in a criminal case. Interestingly, they did so in a "politically sensitive" trial of Native Americans who opposed the way their people were treated by the federal government. In United States $v$. Red Feather, 127 a 1975 case involving the federal takeover of the Native American village of Wounded Knee in 1973, ${ }^{128}$

proper respect for the role of the jury in the criminal justice system. The essential purposes of the jury are twofold. First, the jury temper [sic] the application of strict rules of law by bringing the commonsense judgment of a group of laymen to the case. Second, the jury stand [sic] as a check on arbitrary enforcement of the law.... The legitimacy of a jury verdict depends on the ability of the jury to perform these two functions.

Id. at 596, 452 N.E.2d at 197-98 (Liacos, J., concurring) (footnotes omitted).

122. State v. Brechon, 352 N.W.2d 745 (Minn. 1984).

123.

As a general rule in the field of criminal law, defendants are not required to determine in advance what evidence they will use in their cases. The state is required to bear its burden of proof before the defendants determine whether or not they will offer any evidence and, if so, what evidence they will offer. The use of a motion in limine against a defendant in a criminal case, particularly one as broad in scope as in this case, is questionable considering the constitutional rights of defendants.

Id. at 747-48.

124. Id. at 751 .

125. Id.

126. Id. at 751-52 (Wahl, J., concurring).

127. 392 F. Supp. 916 (D.S.D. 1975).

128. For an excellent review of the historical circumstances leading to the federal siege 
the defendants were charged with interfering with law enforcement officials engaged in the performance of their official duties. Before the trial began, the government submitted a motion in limine that the court characterized as "anticipat[ing] the defendants' plan to adduce evidence to show that United States marshals and agents of the Federal Bureau of Investigation on duty at Wounded Knee during the 1973 occupation were not performing their official duties lawfully."129 The government sought to preclude all evidence relating to such a defense. The court, however, ruled that whether these officials were performing their duties lawfully was an element of the crime charged and was therefore a permissible defense to be raised at trial. The court denied the government's motion in limine and allowed the defense to present evidence that law enforcement officials were actively engaged in unlawful activities.

Since Red Feather, federal prosecutors have used the motion in limine most frequently in efforts to exclude the insanity defense ${ }^{130}$ from ordinary criminal trials. Since its first such use in 1981,131 the motion has been extensively and successfully employed by federal prosecutors to bar the insanity defense, particularly when based upon an accused's pathological gambling in prosecutions for theft. ${ }^{132}$ In contrast to the states' judicial response, however, federal courts seem less concerned about the impact of such motions on defendants' rights. ${ }^{133}$ Of eight reported decisions, only one court considered the motion's

of Wounded Knee in 1973, see Akwesasne Notes, VoIces From Wounded KNeE, 1973, IN THE Words of THE Participants 1-33 (1974). Wounded Knee, located on the Pine Ridge Reservation in South Dakota, is historically significant to the Native American people because it was the site of the last "battle" in the Indian Wars, where U.S. Army troops killed $\mathbf{3 0 0}$ unarmed Sioux people in 1890. In 1973, it was the place where 200 American Indian Movement (AIM) members declared themselves an independent Sioux nation in response to human rights violations against the Indian people living on the Pine Ridge Reservation. See id. at 33-65.

129. Red Feather, 392 F. Supp. at 920.

130. FED. R. CRIM. P. 12.2 (when an accused intends to rely on an insanity defense, she must serve timely notice upon the prosecution before trial).

131. United States v. Veatch, 647 F.2d 995 (9th Cir. 1981).

132. The federal prosecutor's motion in limine has precluded insanity defenses when not timely served, United States v. Veatch, 647 F.2d 995 (9th Cir. 1981); United States v. Buchbinder, 796 F.2d 910 (7th Cir. 1986), when based upon compulsive gambling, United States v. Davis, 772 F.2d 1339 (7th Cir. 1985) (forgery and conversion of U.S. Treasury checks); United States v. Torniaro, 735 F.2d 725 (2d Cir. 1984) (interstate transportation of stolen property); United States v. Lewellyn, 723 F.2d 615 (8th Cir. 1983) (mail fraud), and when based on narcotics addiction, United States v. Lyons, 731 F.2d 243 (5th Cir. 1984). The fourth circuit declined to issue an absolute in limine order precluding such defense prior to trial, but ruled the trial evidence insufficient to permit a jury instruction. See United States v. Gillis, 773 F.2d 549 (4th Cir. 1985); United States v. Gould, 741 F.2d 45 (4th Cir. 1984).

133. Because the insanity defense must be disclosed to the prosecution prior to trial, FED. R. CRIM. P. 12.2, the motion in limine to exclude a proposed insanity defense may properly be converted into a prosecution's discovery mechanism against an accused. For this reason, when a statute compels the defense to serve pretrial notice in order to assert a defense, the motion in limine does not render the same damage to defendant's constitutional rights as when the prosecutor employs the motion to challenge a non-notice defense. See also FED. R. CRIM. P. 12.1 (notice of alibi); FED. R. CRIM. P. 12.3 (proposed) (notice of defense based on 
effect on the accused's sixth and fourteenth amendment right to present a full defense, and curtly rejected it. ${ }^{134}$

Federal prosecutors have also attempted to use the motion in limine to prevent a duress defense from being raised in the ordinary criminal trial. For example, in United States v. Shapiro, ${ }^{135}$ the Ninth Circuit affirmed the government's in limine motion to prohibit a duress defense in a drug conspiracy indictment. In her pretrial offer of proof, the defendant claimed that she participated in the drug transaction because she feared her life was in danger, and she did not have a reasonable opportunity to escape. The court rejected the proffered evidence as a matter of law, finding that there was "no immediacy of the threatened harm" and that the defendant "offered no credible evidence that she had no opportunity to escape." 136 The court ruled that there was no factual issue for jury consideration since "no reasonable jury could have concluded that Shapiro acted under an immediate threat of serious bodily injury, with no opportunity to escape."137

Two years later, the Ninth Circuit reconsidered whether such a pretrial determination of the sufficiency of a duress defense impermissibly intruded into the jury's factfinding responsibility. In United States $v$. Contento-Pachon, ${ }^{138}$ the appellate court reversed a lower court's in limine ruling that had precluded a duress defense at a drug trial. The trial court had rejected, as a matter of law, the sufficiency of the defendant's offer of proof, which attempted to establish that he smuggled cocaine because his life and the life of his family had been threatened, and that he had no reasonable means of escape because he believed the Columbian police were corrupt. Avoiding the sweeping conclusion of Shapiro, a 3-judge appellate panel found that the reasonableness of defendant's beliefs was an issue of fact for a jury to decide. The court cast doubt upon its holding in Shapiro when it declared that "[f]actfinding is usually a function of the jury, and the trial court rarely rules on a defense as a matter of law." 139 The court concluded that the defendant's right to have the jury resolve the disputed factual issues was violated in Contento-Pachon because "the trier of fact should have been allowed to con-

public authority); 40 CRIM. L. REP. (BNA) 2143 (Nov. 12, 1986) (other examples when pretrial disclosure may be necessary).

134. In United States v. Davis, 772 F.2d 1339, 1344 (7th Cir. 1985), the trial court indicated that it was "a rare case in which a witness's testimony is not fit to be heard by a jury and such a determination is not to be lightly made." The appellate court affirmed, concluding the defendant was not prevented from presenting a defense, but rather "could not present a defense because he had no relevant, non-confusing evidence which he chose to present." Id. at 1348.

135. 669 F.2d 593 (9th Cir. 1982).

136. Id. at 596-97. In an accompanying footnote, the court affirmed the trial judge's refusal to admit the defense because it agreed with the trial court's determination that the defendant had several avenues of escape. Id. at 597 n.4. Customarily, however, the jury decides whether a defense is sufficient to acquit an accused.

137. Id. at 597.

138. 723 F.2d 691 (9th Cir. 1984).

139. Id. at 693. 
sider the credibility of the proffered evidence." 140

Despite this encouraging language in Contento-Pachon, recent federal cases point to increasingly frequent use by the government of broad motions in limine in politically sensitive cases. ${ }^{141}$ While state prosecutors have attempted to preclude justification defenses in prison escape and anti-nuclear demonstration cases with the motion, federal prosecutors have routinely gained judicial approval of the motion in similar federal cases during the same period.

In United States v. Peltier, ${ }^{142}$ for instance, the Ninth Circuit upheld an in limine ruling that prevented a duress defense from being raised in a prison escape case. Leonard Peltier, a leader of the American Indian Movement during the Wounded Knee uprising, argued that escape "was his only possible response to his fear that the United States government had arranged to have him killed while in prison."143 Despite characterizing the defense's offer of proof as "present[ing] some close questions about materiality and relevancy," 144 the court affirmed the

140. Id. at 695 .

141. Contento-Pachon appeared to represent a reconsideration of the Shapiro court's approval of the motion. Yet two years later, a Ninth Circuit panel declined to amplify, much less extend its brief reference to a jury's fact-finding powers despite reversing an in limine order. United States v. Williams, 791 F.2d 1383 (9th Cir. 1986). Because there are a limited number of reported decisions, there is no clear trend in judicial approval, or in the prosecutor's use, of the motion in limine in the ordinary federal criminal trial. The insanity defense cases, see notes 131-132 supra, may suggest federal courts are not as concerned as state courts with the motion's effect upon the accused's constitutional rights. But the motion in limine to strike a pretrial notice defense, like insanity, is distinguishable from its use in other situations. See note 133 supra.

The Supreme Court's decision in Crane v. Kentucky, 106 S. Ct. 2142 (1986), may signal a departure from the federal courts' failure to expressly address the motion's consequences to the accused's right to obtain a fair trial. In reversing a trial court's in limine ruling, the Supreme Court emphasized that the "blanket exclusion of the proffered testimony ... deprived [the defendant] of a fair trial." Id. at 2146. The court added that it was "breaking no new ground in observing that an essential component of procedural fairness is an opportunity to be heard. That opportunity would be an empty one if the State were permitted to exclude competent and reliable evidence . . . central to the defendant's claim of innocence." Id. at 2146-47.

142. 693 F.2d 96 (9th Cir. 1982) (per curiam).

143. Peltier, 693 F.2d at 97. Leonard Peltier was convicted for the murders of two FBI agents in 1977. At trial, Peltier claimed the FBI had framed him based on his role as the leader of the American Indian Movement (AIM) and because of tensions between the FBI and AIM on the Pine Ridge Reservation since the Wounded Knee incident. Peltier claimed that the FBI manufactured evidence against him, and that the government had withheld exculpatory evidence showing that the agents had been killed by a different gun than the one allegedly recovered from Peltier. The Eighth Circuit recently denied Peltier's motion to vacate the judgment and for a new trial stating " $[t]$ here is a possibility that the jury would have acquitted Leonard Peltier had the records and data improperly withheld from the defense been available to him ... [but we are not convinced,] from a review of the entire record, that had the data and records withheld been made available, the jury probably would have reached a different result." United States v. Peltier, 800 F.2d 772, 779-80 (8th Cir. 1986) (emphasis in original), aff' $g$ order, 609 F. Supp. 1143 (D.N.D. 1985).

144. Peltier, 693 F.2d at 98. According to Peltier's trial counsel, Bruce Ellison, the defense proffered evidence, including 13 witnesses and 150 independently corroborating documents, to establish that the government plotted to kill Peltier by hiring another inmate to encourage him to escape and to have Peltier killed during the incident. Mr. Ellison stated 
government's use of the motion in limine and precluded the duress defense. The court ruled as a matter of law that Peltier failed to meet his burden of showing that "there was not a reasonable opportunity to avoid the perceived danger." 145 As in its expansive ruling in Shapiro, ${ }^{146}$ the appellate court defined reasonableness as an issue for the court to determine, not the jury.

The court then opined that the proper course of action for a "reasonable prisoner" fearing for his life at the hands of federal agents "would be to advise the warden, the prison counselors and any other counsel or friends on the inside or outside of the prison ... and make an appropriate request for secure and safe custody until the factual situation could be sorted out." 147 In the court's opinion, "[n]o imaginable set of circumstances could be drawn from the [defendant's] offers of proof to justify the armed jail break that took place."148

Perhaps the Ninth Circuit's reconsideration of the jury's role as the factfinder in Contento-Pachon ${ }^{149}$ might have led to a different ruling if Peltier were being decided today. ${ }^{150}$ But the differing judicial attitudes of a federal court approving the government's motion in limine in Peltier, and a state court denouncing an identical motion in the same year in Commonwealth v. O'Malley, ${ }^{151}$ could not be more striking.

In June, 1986, the Ninth Circuit did reverse an in limine trial order that had precluded a duress defense in another prison escape case: In United States $v$. Williams, ${ }^{152}$ the appellate court determined that the defendant's offer of proof was sufficient to support a duress defense as a matter of law. The court's decision, however, did not make any reference to the dicta in Contento-Pachon regarding the jury's factfinding powers $^{153}$ and did not, therefore, address the motion in limine's effect upon the accused's right to trial by jury.

The federal government has also used the motion in limine with increasing frequency to preclude a necessity defense in cases arising from antinuclear demonstrations. In United States v. Best, ${ }^{154}$ the defend-

that, at the time of the escape, Leonard Peltier wore long hair and his accomplice, the alleged government informant, had short hair. According to Mr. Ellison, a third inmate with long hair like Peltier's joined the duo at the last moment and was shot in the back when the prison authorities foiled the escape. Telephone conversation with Bruce Ellison (Jan. 8, 1987).

145. Peltier, 693 F.2d at 98.

146. 669 F.2d 593 (9th Cir. 1982).

147. Peltier, 693 F.2d at 98.

148. Id. In 1984, Peltier was declared a "prisoner of conscience" by Amnesty International, a human rights organization that campaigns worldwide to free prisoners of conscience and to safeguard their rights while incarcerated.

149. 723 F.2d 691 (9th Cir. 1984).

150. But see United States v. Williams, 791 F.2d 1383 (9th Cir. 1986); United States v. Dorrell, 758 F.2d 427 (9th Cir. 1985); texts accompanying notes 152, 163 infra.

151. 14 Mass. App. Ct. 314, 439 N.E.2d 832, review denied, 387 Mass. 1102, 440 N.E.2d 1177 (1982).

152. 791 F.2d 1383 (9th Cir. 1986).

153. See notes $139-140$ supra and accompanying text.

154. 476 F. Supp. 34 (D. Colo. 1979). 
ants were charged with trespassing on the site of a nuclear power plant. The government filed a pretrial motion in limine in the district court "seeking an advance ruling on evidentiary questions," 155 and an order prohibiting the defendants from presenting the defense of necessity. The trial court granted the motion concerning the evidentiary items, and established narrow guidelines for the justification defense which it ruled were not met in the offer of proof presented by the defense. ${ }^{156}$ Consequently, the court ordered that, without an appropriate offer of proof, "there will be no jury voir dire ..., no opening statement ...., no testimony ..., no instructions ... , and ... no final argument as to a justification defense."157

Three years later, in United States $v$. Seward, ${ }^{158}$ the Tenth Circuit affirmed Best, concluding that the trial court had not abused its discretion by precluding the necessity defense prior to trial. The appellate court agreed with the trial judge's strict standards for the applicability of the necessity defense, ruling that it "can be asserted only by a defendant who was confronted with such a crisis as a personal danger ... [and] is obviously not a defense to charges arising from a typical protest."159 The court briefly noted that the defendants had been able to express their "personal beliefs," and concluded that the in limine order had not placed "undue restrictions on the [defendant's] right to testify as a practical matter." 160

In 1985, in United States v. Dorrell, ${ }^{161}$ the federal government moved in limine to exclude a necessity defense in another type of civil disobedience protest case. ${ }^{162}$ In Dorrell, the defendant was indicted for unlawfully entering an Air Force Base where MX missiles were being assembled, and for damaging government property by spray painting the building with political slogans. A 3-judge panel for the Ninth Circuit affirmed the district court's granting of the government's motion in

155. Id. at 41 .

156. The court established "very narrow limits of justification defenses" and indicated that the court, not the jury, decides whether the offer of proof meets, among other things, the following guidelines:

1. A direct causal relationship [existed] between the defendants' actions and the avoidance of the perceived harm ....

2. The act to be prevented by defendant's conduct was criminal under the laws of the United States .... .

3. The alleged criminal act which defendants wanted to stop was one occurring in their presence, and was one which could subject them to immediate harm which a reasonable man would think could be eliminated by defendants' conduct ....

4. There was no alternative available to defendants to accomplish their purId. at 48. pose which did not involve a violation of the law ....

157. Id. at 49 .

158. 687 F.2d 1270 (10th Cir. 1982).

159. Id. at 1276 .

160. Id. at 1277 .

161. 758 F.2d 427 (9th Cir. 1985).

162. Id. at 429. The government learned of the accused's intention to rely upon a necessity defense from defense counsel's intimations during a pretrial discovery conference. 
limine and endorsed the use of the motion to determine the admissibility of a necessity defense. Like the later Ninth Circuit panel in United States $v$. Williams, the court found the reasonableness of the defense to be a matter of law to be decided by the judge. ${ }^{163}$ The court concluded that there were other legal alternatives available to redress the defendant's concerns regarding nuclear war, and that no direct causal relationship existed between defendant's conduct and the harm he sought to remedy. ${ }^{164}$

Later that year, the Eleventh Circuit, in United States v. Montgomery, ${ }^{165}$ affirmed the government's use of the motion in limine to preclude defenses based on necessity and international law. In Montgomery, the defendants were members of "Pershing Ploughshares," a group that opposed the production and spread of nuclear weapons. The defendants entered a defense plant where they hammered and poured blood on nuclear and conventional missile launchers owned by the United States Army. The Eleventh Circuit panel followed Dorrell and held that the proffered evidence was insufficient to establish the necessity defense, and that a justification defense based upon international law was properly rejected by the trial court.

Neither Seward nor Dorrell nor Montgomery addressed the motion in limine's impact upon the fundamental right of the accused to a fair trial and to present a full defense-the very concerns emphasized by state court opinions in ruling upon similar prosecution motions in limine in state antinuclear demonstration cases. The Ninth, Tenth, and Eleventh Circuits approved the government's in limine practice and established strict legal thresholds for the necessity defense.

\section{Judicial Acceptance of the Broad Motion in Limine in Recent Politically Sensitive Cases}

As federal appellate courts continue to sanction broad use of the motion in limine, the government's use of the motion in politically sensitive trials increases dramatically. In 1985, three other politically sensitive cases moved through federal district courts in Arizona, and a fourth did so in a federal district court in New Jersey. In each of these cases, the government employed motions in limine to limit justification and other anticipated defenses from trials.

In this section, I discuss in detail each of these cases: United States $v$.

163. Id. at 430; see notes 152-153 supra and accompanying text; see also United States v. Cottier, 759 F.2d 760 (9th Cir. 1985) (precluding defenses based on necessity and international law in a criminal prosecution arising from defendants' antinuclear protest activities).

164. Dorrell, 758 F.2d at 432-33. As to the first point, the court found: "To accept Dorrell's position would amount to recognizing that an individual may assert a defense to criminal charges whenever he or she disagrees with a result reached by the political process." Id. at 432. As to the second point, it stated: "Dorrell failed as a matter of law to establish that his [actions] could be reasonably anticipated to lead to the termination of the MX missile program and the aversion of nuclear war and world starvation." Id. at 433.

165. 772 F.2d 733 (11th Cir. 1985). 
Fox, ${ }^{166}$ an antinuclear demonstration case in which the government relied upon extraordinary pretrial measures to preclude a necessity defense; United States $v$. Martinez, ${ }^{167}$ in which a prosecution's motion in limine excluded an anticipated defense in the trial of an activist, Chicano lawyer; United States $v$. Rosenberg, ${ }^{168}$ in which the government's motion sought to prohibit the defendant's use of particular words or phrases in any proposed defense; and United States v. Aguilar, ${ }^{169}$ in which a prosecution's motion in limine succeeded in precluding four different defenses in the trial of eleven sanctuary workers who opposed federal immigration policy.

\section{A. United States v. Fox}

On May 5, 1985, Margaret Fox and Sally Manshardt were arrested after unlawfully entering the Davis-Monthan Air Force base in Tucson, Arizona and dancing atop an Air Force building used to train personnel for European-based, ground-launched cruise missiles. ${ }^{170}$ A subsequent prosecution information charged each with violating 18 U.S.C. § 1382 by reentering a military reservation after having been previously barred.

Anticipating the government's motion in limine following the Ninth Circuit's decision in United States $v$. Dorrell, ${ }^{171}$ counsel for the defendants affirmatively served notice of their intention to use a necessity defense at trial. The government, as anticipated, moved in limine to preclude the defense. ${ }^{172}$ Because the case would be tried before a judge and not a jury, the government's motion did not argue that the defense should be excluded because it would prejudice the factfinder. The government instead relied extensively on Dorrell and argued that a necessity defense should be barred as a matter of law when its elements cannot be established prior to trial. The prosecution contended that defendants Fox and Manshardt could establish neither that a causal link existed between the defendants' protest and a change in U.S. policy on

166. No. CR-85-152-TUC-RMB (D. Ariz. filed Dec. 31, 1985).

167. No. CR-85-029-TUC-WDB (D. Ariz. filed Jan. 15, 1985), rev'd, 785 F.2d 663 (9th Cir. 1986).

168. Crim. No. $84-360$ (D.N.J. filed Feb. 28, 1985), aff'd, 806 F.2d 1169 (3d Cir. 1986) (2-1 decision).

169. Crim. No. CR-85-008-PHX-EHC (D. Ariz. filed Jan. 10, 1985) (currently being appealed to 9th Cir., conversation with Karen Snell, attorney for defendant Aguilar, Dec. 23, 1986).

170. See generally Turner, The Disarming of Two Dancing Activists, Nat'l L.J., Dec. 22, 1986, at 6 . The defendants were members of the Greenham Common Women, a group which has opposed the deployment of cruise missiles in England and have stood vigil outside the United States Air Force base in Southern England since 1982.

171. 758 F.2d 427 (9th Cir. 1985); see notes 161-164 supra and accompanying text.

172. Government's Motion in Limine to Preclude Defendant from Using a "Necessity" Defense at 1, United States v. Fox, No. CR-85-152-TUC-RMB (D. Ariz. filed Dec. 31, 1985), rev'd sub nom. United States v. United States Dist. Court, No. 86-7049 (9th Cir. June 4, 1986). 
nuclear weapons, nor that no reasonable alternative to peaceful protest of the government's nuclear policy existed.

The defense agreed that Dorrell was controlling and responded ${ }^{173}$ with an offer of proof which included nine separate affidavits to provide factual support to meet Dorrell's 3-prong test ${ }^{174}$ of imminent harm, ${ }^{175}$ causality, ${ }^{176}$ and unavailability of reasonable alternatives to the action taken. ${ }^{177}$ In essence, the defense counsel argued that the determination of whether or not defendants' actions were reasonable and met the legal standard of Dorrell was a factual matter to be decided by the factfinder at trial, and not by the court prior to the commencement of trial. In its reply memorandum, ${ }^{178}$ the government strenuously argued that "[a] necessity defense is entirely inappropriate to acts of civil disobedience [and] even if it were appropriate, the defendants cannot establish its elements" 179 as a matter of law.

On October 9, 1985, Judge Richard M. Bilby denied the government's motion in limine. ${ }^{180}$ In finding the defendant's proffered evidence sufficient to allow evidence of the necessity defense to be presented at trial, the court limited each side's expert testimony to a maximum of four witnesses to be presented over a 2-day period. On October 24, 1985, the government sought reconsideration of the

173. Defendant's Response to Government's Motion in Limine to Preclude Use of a Necessity Defense at 2, Fox (No. CR-85-152-TUC-RMB) [hereinafter Defendant's Response].

174. See Dorrell, 758 F.2d at $430-31$.

175. Defense submitted the affidavits of five individuals who were prepared to testify that nuclear war, either by actual policy or by accident, is imminent. They included Robert Aldridge, an aerospace engineer; Alex Dely, a nuclear physicist; Nancy Carroll, a peace researcher; Sidney Lens, author and editor; and Brian Flagg, a local peace activist. Defendant's Response, supra note 173 , at 3.

176. Defense submitted two affidavits and offers of proof to establish that a causal relationship existed between the defendants' actions and a change in the government's nuclear policy. Jack and Felice Cohen-Joppa, national experts on the nonviolent, antinuclear movement, were prepared to testify that direct action against nuclear war leads to a later change of nuclear policy. Jim Douglass, a theologian and spiritual leader of the nonviolent antinuclear movement, compared the defendant's actions to Gandhian and Nuremberg principles which would lead to a change in the government's nuclear policy. Id. at 4 .

177. Defense submitted five affidavits to support their offers of proof that a reasonable doubt exists as to whether the political process is a reasonable, legal alternative to protest government nuclear policy. Sidney Lens described how the American people have no means of affecting the government's policy, either through direct vote or vote of Congress, "where nuclear war is imminent"; Jack and Felice Cohen-Joppa decribed how "other means have not had the effect which civil disobedience has in changing these particular types of policies," and explained why civil disobedience is an effective means in changing unjust or immoral laws; Robert Aldridge's affidavit detailed the executive branch's deception of the American public concerning its nuclear policy and characterized the defendants' acts as a reasonable alternative; Nancy Carroll detailed how legal alternatives to civil disobedience had been exhausted, "all without avail"; and Brian Flagg described the futility of public protest against nuclear policy. Id. at 5.

178. Government's Reply to Defendant's Response to Government's Motion in Limine to Preclude Use of a Necessity Defense, Fox (No. CR-85-152-TUC-RMB).

179. Id. at 7.

180. On Petition for a Writ of Mandamus, Appendix to the Petition at 101, United States v. United States Dist. Court, No. 86-7049 (9th Cir. June 4, 1986) [hereinafter Appendix]. 
court's "decision to allow defendants' use of a 'necessity' defense."181 The government's memorandum reiterated its previous argument that the Ninth Circuit had, as a matter of law, excluded the use of that defense in identical circumstances, and issued a broadside warning that "necessity defense[s] should not be allowed in cases of political protest because the courts are an inappropriate forum for the resolution of political issues."182 In the government's words, "to admit defendant's necessity defense makes the courtroom a forum for the debate over the merits of our government's nuclear policy ... [and] allows defendants to use the judicial system's scarce resources to argue issues properly left to the political process."183 The prosecution challenged the competence of the factfinder to rule upon such a defense in a case considered politically sensitive by the government. ${ }^{184}$

Judge Bilby denied the government's motion to reconsider his earlier in limine ruling. ${ }^{185}$ Dissatisfied with this ruling, the prosecution submitted a second motion for reconsideration on December 6, 1985, stating "the government strongly contests defendant's legal argument that they may present a defense of necessity."186 In its accompanying memorandum, the government sought a novel ruling from the court, comparable to a party's motion for summary judgment in a civil case. The requested ruling closely resembled a criminal defense attorney's pretrial motion to dismiss, or a motion for a directed verdict of acquittal, except for the fact that it was the prosecution seeking a dismissal of its own charges. ${ }^{187}$ In essence, the prosecution asked the court to as-

181. Government's Motion to Reconsider Its Motion in Limine to Preclude Use of a Necessity Defense, Fox, No. CR-85-152-TUC-RMB [hereinafter Government's Motion to Reconsider].

182. Id. at 103 .

183. Id. at 104; see also United States v. Quilty, 741 F.2d 1031, 1033 (7th Cir. 1984); note

200 infra and accompanying text.

184. The prosecution argued that:

Neither a trial judge nor a jury has been popularly elected to make controversial political decisions. ... [To] allow defendant's necessity defense [in this case] ... . places an appointed judge in a position to render void, without an explicit Constitutional basis, the laws passed by elected representatives. It encourages chaos by presenting the opportunity for subjective, individual moral visions to preempt collectively chosen social laws.

Government's Motion to Reconsider, supra note 181, at 105.

185. Appendix, supra note 180 , at 107.

186. Government's Second Motion to Reconsider Its Motion in Limine to Preclude Use of a Necessity Defense at 2, Fox, No. CR-85-152-TUC-RMB [hereinafter Government's Second Motion].

187. In the memorandum accompanying its motion, the government asked the court to: accept the factual allegations (but not the legal conclusions) previously filed by the defendants herein as true and, having done so, further rule whether, assuming the facts are proven, they are as a matter of law legally sufficient to constitute a necessity defense. If the court finds that such is sufficient to make out a prima facie defense of necessity which could then be considered by the trier of fact, then the government would request that the court dismiss the information. If the court rules that these "facts" would not constitute a prima facie necessity defense as a matter of law, then the government would request that the court vacate its [previous in limine] ruling ... 
sume, for the purpose of the ruling, the truth of the facts asserted by the defendant, and to find such facts insufficient as a matter of law to constitute a defense. If the court made a contrary finding, the government requested the court to then dismiss the charges. The government argued that its right to appeal the trial court's in limine ruling would only be available if the trial judge followed this unique procedure. Judge Bilby declined to follow this procedure and denied the government's second argument for reconsideration. ${ }^{188}$

The prosecution then used an even more unusual criminal procedure in its determined effort to preclude evidence of a necessity defense from being presented at a nonjury trial held in a federal courtroom. It petitioned the Ninth Circuit for a writ of mandamus ${ }^{189}$ against Judge Bilby's pretrial ruling. ${ }^{190}$ The government argued first that the motion in limine is the proper procedure for a district court to follow in reviewing the sufficiency of a pretrial necessity defense. ${ }^{191}$ In the instant case, the government argued, the proffered evidence was insufficient as a matter of law and should be precluded. The government further argued that mandamus is an appropriate remedy because there is no adequate, alternative means of review by either interlocutory or post trial appeal if the defendants are acquitted. ${ }^{192}$ The government's memorandum condemned the necessity defense as "transforming routine criminal prosecutions for trespassing on a military installation ... to broad ranging and time-consuming inquiries concerning the wisdom of nuclear defense policies formulated by the coordinate branches of the government." 193 The government's petition concluded by raising the specter of widespread acts of civil disobedience: "Absent intervention by this Court . . . a [successful] 'nuclear necessity' defense ... will surely serve as the catalyst for future protest activity having the purpose and effect of interfering with vital defense

Appendix, supra note 180 , at 110.

188. Id. at 112.

189. 28 U.S.C. $\S 1651$ provides that federal courts of appeals may issue "all writs necessary or appropriate in aid of their respective jurisdictions and agreeable to the usages and principles of law." 28 U.S.C. $\$ 1651$ (1982).

190. Petition for a Writ of Mandamus to the United States District Court for the District of Arizona, United States v. United States Dist. Court, No. 86-7049 (9th Cir. June 4, 1986) [hereinafter Government's Petition].

191. Id. at 7.

192. The government cited the principles enumerated in Bauman v. United States Dist. Court, 557 F.2d 650, 653-55 (9th Cir. 1977), to guide the appellate court's exercise of mandamus power:

(1) The party seeking the writ has no other adequate means, such as a direct appeal, to attain the relief he or she desires. (2) The petitioner will be damaged or prejudiced in a way not correctable on appeal. ... (3) The district court's order is clearly erroneous as a matter of law. (4) The district court's order is an oft-repeated error, or manifests a persistent disregard of the federal rules. (5) The district court's order raises new and important problems, or issues of law of first impression.

557 F.2d at 654-55 (citations omitted); see Government's Petition, supra note 190, at 17. 193. Government's Petition, supra note 190, at 19. 
functions of the armed forces." 194

The defense responded to the government's petition by arguing that this was not an exceptional circumstance where a trial court made a clearly erroneous ruling which would require application of this extraordinary remedy, but rather a factual, evidentiary determination made within the court's discretion. ${ }^{195}$ The defense concluded that "even if this Court disagrees with the trial court's decision, ... it would be improper to issue a mandamus interfering with the District Court's discretionary judgment." 196 Judge Bilby's ruling, argued the defense, merely decided that the "defendants have made the factual showing required under the law" in order to present the defense. A mandamus, according to the defense, "should not issue to consider factual determinations specific to individual cases." 197

On June 4, 1986, a 3-judge panel of the Ninth Circuit reversed Judge Bilby's in limine ruling in a terse, 40 -word opinion. ${ }^{198}$ In analyzing the substantive decision in United States $v$. Fox, the Ninth Circuit determined, as a matter of law, that the very nature of the American political system precludes a required element of the necessity defense-the unavailability of reasonable alternatives for political expression-in trials of political dissidents. The court's brief opinion suggests that it agreed with a 1984 Seventh Circuit ruling which affirmed a trial court's refusal to instruct a jury on a necessity defense because of "the defendant's failure to resort to the political process."199 According to the Seventh Circuit, such recourse would have resulted in

thousands of opportunities for the propagation of the antinuclear message: in the nation's electoral process; by speech on public streets, in parks, in auditoriums, in churches and lecture halls; and by the release of information to the media, to name only a few. ${ }^{200}$

While Fox may have sounded the death knell of the necessity defense in politically sensitive trials in the Ninth Circuit, the case is also important as an example of the extreme measures federal prosecutors have taken to prevent such a defense from even being raised in political trials. The reasons commentators and judges have praised the motion

194. Id. at 22. The potential disruption was said to encompass not only "Davis-Monthan and the 24 other Air Force bases located within the Ninth Circuit" but could "potentially affect the fifteen Army and numerous Navy bases situated within the Ninth Circuit as well." Id. at 22 n.4.

195. Reply to Petition for Writ of Mandamus to the United States District Court for the District of Arizona at 3, United States v. United States Dist. Court, No. 86-7049 [hereinafter Reply to Petition].

196. Id. at 10.

197. Id. at 11.

198. "We grant petitioner's request for a writ of mandamus. The availability of alternative avenues for political action bars the necessity defense in this case. . . . On remand the district court is directed to enter an order granting petitioner's motion in limine." United States v. United States Dist. Court, No. 86-7049 (9th Cir. June 4, 1986) (before Wallace, Pregerson \& Kozinski, JJ.) (citation omitted).

199. United States v. Quilty, 741 F.2d 1031, 1033 (7th Cir. 1984).

200. Id. 
in limine as a beneficial litigation tool were entirely absent from this case. The government did not use the motion in limine in Fox as a means to prevent the jury's exposure to prejudicial material, because the defendants were tried before a judge, not a jury. The concern about using scarce judicial resources to allow presentation of material which will later be found inadmissible was answered when the trial court issued its order limiting testimony on the motion to only four witnesses over two days.

The government revealed its reason for making this motion in its petition for mandamus relief to the Ninth Circuit. There, the government expressed fear that if the necessity defense was permitted to be heard as a valid defense in this case, it would "foster other actions calculated to disrupt the ability of the military, to conduct operations vital to the national defense."201 The defense argued that it was speculative at best for federal prosecutors to conclude that mass public demonstrations would occur as a result of one federal district court permitting the necessity defense to be raised in one trial, even if the defense were ultimately successful. ${ }^{202}$ Certainly, however, a public trial in which the necessity defense was raised would allow more people to be educated about the advantages and disadvantages of federal nuclear policy.

The Ninth Circuit approved the motion in limine to preclude the necessity defense in Fox because it believed the citizenry has adequate democratic avenues to protest government policy. Yet, in precluding the necessity defense before it was raised, the court also closed off one of the routes through which citizens learn about government policies, and by which they learn of their fellow citizens' understanding of those policies. In granting the government's motion, the court eliminated the public trial forum from the democratic menu of citizen access to information about what its government is doing. Thus, the motion in limine in political trials can serve to suppress information from the public, and limit the citizenry's ability to participate intelligently in the democratic process.

Though Fox may be an extreme procedural example, its precedent for using the motion in limine to preclude a necessity defense is alarming. Its application in other politically sensitive trials, even in a less extreme procedural form, would deny an accused her right to be judged by either an independent judiciary or an impartial jury. In addition, it leaves open the serious question, despite government denials, of whether the motion in limine is also a tool for the suppression of truth in politically sensitive criminal cases.

201. Government's Petition, supra note 190, at 21.

202. Reply to Petition, supra note 195 , at 5-6. 
B. United States v. Martinez 203

Francisco Eugenio ("Kiko") Martinez practiced law in New Mexico and Colorado after graduating from law school in 1971.204 He specialized in advocacy of the rights of Chicanos and other minorities, migrant workers, prisoners, and students, and was active in the Crusade for Justice, a Chicano-rights center in Denver.

In March, 1973, one of the center's workers was killed in a shootout with Denver police. Later that year, Denver police investigated the mailing of three letter bombs allegedly sent in revenge for the activist's death. Their investigation of these bombs resulted in a 7-count federal indictment and an 11-count state indictment against Martinez, charging him with possession of unregistered explosives and the sending of explosives through the United States mail. Shortly after his indictment, Martinez fled the jurisdiction, claiming he could not receive a fair trial in a political climate where police had orders to shoot him on sight and where media accounts characterized him as a "terrorist and a save-theworld zealot."205

In September, 1980, Martinez was apprehended while crossing the border from Mexico into Arizona and brought to trial on the outstanding federal indictment. The indictment was severed by Judge Fred Winner, resulting in Martinez facing a separate trial for each of the three bombing incidents.

On January 29, 1981, the third day of the first trial, the defense moved for a mistrial based upon jury misconduct. ${ }^{206}$ Judge Winner denied the motion. That evening, the judge invited the prosecutors, certain court personnel, and government witnesses to his hotel room to discuss plans to place hidden cameras in the courtroom to record what he asserted was a defense conspiracy to intimidate the jury. He stated that he wanted to find a basis for declaring a mistrial after the defense conspiracy had been filmed. The following morning, before the trial resumed, the United States Attorney from Denver arrived and met privately with Judge Winner. Following this meeting, government prosecutors joined the defense mistrial motion citing extensive publicity surrounding the jurors' misconduct. Judge Winner granted the motion

203. No. CR-85-029-TUC-WDB (D. Ariz. filed Jan. 15, 1985), rev'd, 785 F.2d 663 (9th Cir. 1986).

204. For the background of events leading to the charges brought against Frankie Eugenio Martinez in 1981, see United States v. Martinez, 785 F.2d 663 (9th Cir. 1986); United States v. Martinez, 667 F.2d 886 (10th Cir. 1981), cert. denied, 456 U.S. 1008 (1982); see also Martinez v. Winner, 771 F.2d 424 (10th Cir. 1985); United States v. Martinez, 744 F.2d 76 (10th Cir. 1984); United States v. Martinez, 681 F.2d 1248 (10th Cir. 1982); Lobato, Kiko's Attorneys Will Seek Acquittal and/or New Trial, The Valley Courier, Nov. 19, 1986, at 15; Francisco "Kiko" Martinez Saga (Francisco E. Martinez Defense Committee, Alamosa, Colorado, published March, 1985) [hereinafter Martinez SaGA].

205. MARTinez SAGA, supra note 204, at 2.

206. The factual material referred to at Martinez' first trial is summarized in the Tenth Circuit decision, Martinez, 667 F.2d at 888. 
and scheduled a new trial. On retrial before Judge John Kane in Denver, the defense learned of the ex parte meeting in the judge's hotel room, and moved to dismiss the three counts involved in the first trial on grounds of double jeopardy based upon judicial and prosecutorial misconduct. Judge Kane denied the motion. Martinez appealed, and the Tenth Circuit remanded the case for reconsideration of the defendant's motion to dismiss. A federal judge from outside the district was assigned to the case and granted the defense motion, thus dismissing three of the seven counts against Martinez. This decision was subsequently affirmed by the Tenth Circuit Court of Appeals. ${ }^{207}$

Eventually, the remaining counts of the federal indictment, as well as the entire state indictment, would also fall. The Denver District Attorney dismissed the state indictment in September, 1981 following the Tenth Circuit's affirmance. In November, 1982, a federal jury acquitted Martinez of two counts, and two years later in November, 1984, the United States Attorney moved to dismiss the remaining federal charges. ${ }^{208}$

Despite the dismissal of all the bomb-related charges, Martinez' legal difficulties were not yet over. Two months after the last federal charges were dismissed, Martinez was re-indicted by a federal grand jury in Tucson, Arizona, and charged with making false statements to a federal customs official, a United States marshal, and a United States magistrate in 1980 when he gave a false name after his arrest for illegally crossing the border. ${ }^{209}$ His lawyers filed a motion to dismiss the indictment on grounds of vindictive prosecution and in May, 1985 Judge Browning granted their motion. ${ }^{210}$ However, a Ninth Circuit 3judge panel reversed Browning's decision in March, 1986 and ordered Martinez to stand trial on the new 3-count indictment. ${ }^{211}$

The government had filed a motion in limine prior to the district

207. Id. at 888-89. On remand, the defendant also moved to dismiss all charges on grounds of prosecutorial and judicial misconduct. Judge Eubanks denied the motion and a special Tenth Circuit panel composed of judges from outside the circuit affirmed. Id. at 888$89,892$.

208. A review of the legal proceedings leading to the dismissal of the 1973 indictment is included in the Ninth Circuit's "Facts and Proceedings Below" in Martinez, 785 F.2d at 66465.

209. 18 U.S.C. § 1001 (1982) (false statements to federal officers concerning identification and citizenship); 18 U.S.C. $\$ 1623$ (1982) (false declarations before a court). Martinez is alleged to have made false statements at an indigency hearing on September 5, 1980, following his arrest for eluding inspection by INS officers, 8 U.S.C. $§ 1325$ (1982), and making a false claim of U.S. citizenship, 18 U.S.C. \$ 911 (1982). See Martinez, 785 F.2d at 664-65.

210. According to the Ninth Circuit's decision, Judge Browning's dismissal was based upon the government's failure to rebut the appearance of vindictiveness, not upon a finding of actual vindictive prosecution. The Arizona re-indictment was returned two months after the U.S. Attorney dropped the last counts of the criminal indictment following the death of a key government witness. Government prosecutors contended that the outcome of the Colorado trials did not influence their decision to prosecute Martinez on the 1980 Arizona offense. They explained the 2-year delay as necessary to verify fingerprints and to seek financial information. Martinez, 785 F.2d at 665; see also MARTINez SAGA, supra note 204, at 3.

211. The Ninth Circuit stated that "this case is an inappropriate one to invoke a pre- 
court's dismissal order. ${ }^{212}$ In their motion, the government sought to preclude "the defendant from presenting any testimony or other evidence in support of his governmental 'frame-up' theory of defense."213 In its supporting memorandum, the government anticipated that Martinez would rely upon a duress defense and argued that the court should bar this defense from trial as a matter of law. The government cited United States v. Peltier ${ }^{214}$ and argued that Martinez, just like Peltier, would be unable "to show the absence of opportunity to avoid the perceived danger."215 According to the prosecution, Martinez could have avoided the danger by remaining in Mexico, but instead "voluntarily chose to return to the United States where the 'danger' existed."216 Referring to the defendant's charge that the prosecution was framing him because it had failed to convict him in any of the three federal trials in Colorado, the government characterized this claim as "grandiose" and the product of one who "believes he is the subject of a giant farreaching conspiracy." 217

The defense did not submit papers in reply to this government motion, but orally denied that defendant intended to use the defense in the way the government anticipated. The result of the government's motion was to require defense counsel to reveal information which alerted the prosecution to the defense theory it would use at trial-the exposure of the government's inability to prove one of the elements of the crime charged. ${ }^{218}$

The government had threatened to recall witnesses from the Colorado cases if the court allowed Martinez to introduce evidence to explain the circumstances under which he left Colorado in 1973.219 The

sumption of vindictiveness" and called the decision to prosecute Martinez in Arizona a result of "legitimate prosecutorial consideration[s]." Martinez, 785 F.2d at 669, 670.

212. Government's Motion in Limine Regarding Evidence of "Duress" and Character, United States v. Martinez, No. CR-85 029-TUC-WDB (D. Ariz. filed Jan. 15, 1985), rev'd, 785 F.2d 663 (9th Cir. 1986).

213. Id. at 1 .

214. 693 F.2d 96 (9th Cir. 1982).

215. Government's Motion in Limine Regarding Evidence of "Duress" and Character, supra note 212 , at 4 .

216. Id. at 5 .

217. Id.

218. Michael Tigar, defense attorney for Martinez, explained that the government's motion in limine incorrectly assumed a duress defense would be used at trial. According to Mr. Tigar, the defense intended to argue that Martinez had a valid, nonfraudulent purpose to adopt a new identity, namely that he feared for his safety because of the 1973 Colorado events and this negated an element of the offense charged. Although the defense rejected the prosecution's characterization of its defense as one of duress, the prosecution's motion in limine required the defense to reveal its legal strategy prior to trial. Telephone conversations with Michael Tigar, December 20, 1986, January 27, 1987.

219. Government prosecutors had submitted a notice of intent to call the Colorado witnesses prior to the commencement of Martinez' trial in October, 1986. Prior to the defendant's sentencing, the government again indicated its intention to call these witnesses to provide information to the court. On both occasions, the government's motion was denied. Conversation with Michael Tigar, defense counsel for Martinez (December 28, 1986). See Notice of Intent to Provide Information Regarding Defendant's Past Criminal Behavior and 
court, faced with these evidentiary issues, elected to grant the government's motion in limine prior to trial and precluded all evidence relating to Colorado events. Thus, Martinez was unable to present any evidence to the jury which would explain that he did not use a false name for an unlawful purpose, but rather because he feared that his personal safety was imminently threatened upon his return to the United States.

In Martinez, the government's motion in limine compelled the defense to disclose its trial strategy prior to the commencement of trial, and ultimately prevented the jury from understanding the circumstances that led Martinez to assume a false identity. In this manner, the motion in limine significantly compromised the defendant's right to present a defense, and facilitated the government's task of bearing its burden of proof at trial. Martinez was finally convicted on one of the three counts (making a false statement to a United States magistrate), and was sentenced to ninety days despite a request from the government for the maximum 5-year period of incarceration.

\section{United States v. Rosenberg}

Although the government has most often used the broad motion in limine to exclude a defense in politically sensitive cases brought in the Ninth or Tenth Circuits, the government filed its most far-reaching motion in limine in United States $v$. Rosenberg, ${ }^{220}$ a federal criminal case in New Jersey. The defendants, Susan Rosenberg and Timothy Blunk, were accused of criminally conspiring to possess explosives, weapons, and false identification. ${ }^{221}$ According to the government, Rosenberg and Blunk were members of a revolutionary black liberation group that believed in the creation of an independent black nation within five states of the Deep South. The government claimed that the group was responsible for a series of crimes, including the highly publicized Brinks robbery, and that the weapons charges against Rosenberg and Blunk were connected to these activities. ${ }^{222}$

Response to Government's "Notice of Intent to Provide Information Regarding Defendant's Past Criminal Behavior," Martinez, No. CR-85-029-TUC-WDB (D. Ariz. filed Jan. 15, 1985). 220. Crim. No. 84-360 (D.N.J. filed Feb. 28, 1985), aff'd, 806 F.2d 1169 (3d Cir. 1986).

221. The indictment charged the defendants with violation of the following statutes: 18 U.S.C. § 371 (1982) (conspiracy); 26 U.S.C. §§ 5861(d), 5871 (1982), 18 U.S.C. § 2 (1982) (possession of unregistered firearms); 18 U.S.C. $\$ \S 842(\mathrm{i})(1)-(2), 844$ (a) (1982) (carrying explosives during commission of felony); 18 U.S.C. $\S \S 922(\mathrm{~h})(2), 924(\mathrm{a})(2)$ (1982) (receiving firearms shipped in interstate commerce while a fugitive); 18 U.S.C. $\$ 1028$ (1982) (possession with intent to use false identification). Joint Appendix at A1-A20, Rosenberg, 806 F.2d 1169 (3d Cir. 1986) (Nos. 85-5360, -5361).

222. Joint Appendix at A90-A122. The government attempted to link the defendants, particularly defendant Rosenberg, to the prison escape of Joanne Chesimard, an alleged member of the Black Liberation Army, and to several other robberies of armored cars. Susan Rosenberg had been indicted on the Nanuet Brinks robbery case, and remained a fugitive from justice until her arrest in the instant case. United States v. Odinga, No. SSS-CR-82-313 (S.D.N.Y. filed Nov. 24, 1982). Both defendants stated that they were communists who consider themselves "revolutionary resistance fighters ... dedicated ... to fighting a system that 
In its motion in limine filed on February 21, 1985, the government cited Rule 402 of the Federal Rules of Evidence in support of its unusual request to preclude and "deem irrelevant for trial" the use of any of thirty-six different words, phrases, or expressions, including the following: "revolutionary alternatives"; "[a] political case, trial, defendants, or detention"; "[m]oral decadence of the United States government"; "revolutionary organizations, revolutionary movements"; "Reagan's repressive legislative package"; and "[p]ublic activists, liberation movements or organizations." 223 The government also sought to restrict any evidence of the defendants' "political, social, religious, racial, ethnic, governmental, [or] diplomatic ... views or beliefs ...."224 In support of their motion, the prosecutors cited no case authority, nor did they submit a memorandum of law.

The defense did not respond to the government's motion on its merits, but characterized it as a "wholly irregular ... extraordinary and overbroad request" made without "any showing as to the irrelevance of the words or matters [the government] wishes to exclude."225 The defense argued that the government's request, if granted, "would abridge the defendants' ability to receive any semblance of a fair trial . . .."226

we and millions of people around the world call U.S. imperialism." Brief for Appellants at 6 . In her remarks at sentencing, Rosenberg began by affirming her commitment to "our revolutionary principles, to our continuing the fight for the defeat of U.S. imperialism, for the liberation of the oppressed nations, for the liberation of women, and for the victory of the socialist world." Id. at 11.

223. Item four of the government's motion in limine asked the court to preclude: any and all views by the defendants on the validity or enforceability of the relevant laws pertaining to this case, including, but not limited to, those relating to the receipt and possession of firearms, explosives, and false identification, as well as the registration of firearms and explosives; and in addition thereto the authority of this Court to conduct a trial in the captioned matter and a jury to render a verdict thereon.

The aforesaid views or beliefs shall include but shall not be limited to, any reference to such verbiage as: 1) terrorist or terrorism; 2) revolution, revolutionaries or revolutionary guerillas, revolutionary defendants, revolutionary organizations, revolutionary movements and revolutionary alternatives; 3 ) U.S. imperialism and resistance thereto; 4) anti-imperialism and anti-imperialist resistance fighters; 5) a political case, trial, defendants or detention; 6) anarchist or anarchy; 7) special forces; 8) South African Regime apartheid; 9) combatants, armed combatants; 10) armed clandestine movement or clandestine forces; 11) socialism or socialistic societies; 12) fascism, fascist government; 13) reference to El Salvador or Nicaragua; 14) prisoners of war; 15) Black nation, Puerto Rican freedom movement; 16) New African liberation movement; 17) Black Liberation Army (BLA); 18) Native American resistance movement; 19) resistance comrades; 20) moral decadence of the United States government; 21) joint terrorist task force; 22) counterinsurgency operations; 23) New York 8; 24) FBI led grand jury "pigs" when used to refer to police officers; 25) Ray Levaseur; 26) urban guerillas; 27) communist workers party; 28) May 19 Communist Workers Party; 29) May 19 Communist organization including Malcolm X and Ho Chi Minh; 30) Reagan's repressive legislative package; and 31) public activists, liberation movements or organizations.

Notice of Motion at 3-4, Rosenberg (Crim. No. 84-360).

224. Id. at 2.

225. Defendant's Motion in Opposition to Government's Motion in Limine at 1-2, Rosen-

berg (Crim. No. 84-360).

226. Id. at 4 . 
The defense posited possible defense theories that would be excluded by such a ruling, including one based upon the government's motivation to plant the illegal material on the defendants because it strongly disagreed with the defendants' political views. The defense argued that the defendants would have to testify as to their own social beliefs, and to beliefs they held about the government, if a jury was to understand the government's possible motive for initiating these prosecutions.

The defense saw the government's motion as a "gag order"227 that sought to deny the defendants "the ability to put before the jury anything regarding their personal and political histories, their beliefs or their principles" which could support the defense. ${ }^{228}$ Although the court denied the government's motion in limine, Rosenberg is instructive in understanding the government's willingness to adopt radical measures in trials of political dissidents-measures which not only intrude upon protected first amendment guarantees, but which make it practically impossible to obtain a fair trial.

\section{United States v. Aguilar ${ }^{229}$}

To date, the most comprehensive government motion in limine to exclude an entire defense accompanied a federal indictment returned in January, 1985, against sixteen individuals accused of violating various immigration statutes. ${ }^{230}$ This case, United States $v$. Aguilar, involved the arrest and criminal prosecution of members of the United States religious community. ${ }^{231}$ Those indicted were representative of a growing national sanctuary movement ${ }^{232}$ that had been openly providing

227. Id. at 5 .

228. Id. at 2. At the defendants' sentencing, the government sought "very substantial" terms of incarceration. Brief for Appellants at 10, Rosenberg, Nos. 85-5360, 5361 (3d Cir. 1985). Judge Lacey sentenced each to 58 years in prison. Defense counsel argued on appeal that the excessive length of these sentences was based on the defendants' communist philosophy. Id. at 11-12.

229. No. CR-85-008-PHX-EHC (D. Ariz., filed Jan. 10, 1985).

230. The indictment charged each of the 16 defendants with conspiracy to violate immigration law, 8 U.S.C. $\$ 1324$ (a), and specific substantive crimes under 8 U.S.C. $\$ 1324$ (a)(1), (2), (3), (4), including transporting, concealing, or harboring aliens, and encouraging or inducing aliens to unlawfully enter or remain in the United States.

231. The month following the indictment, the government dismissed charges against two defendants-Sisters Anna Priester and Anna Waddell. Two other individuals, Cecilio del Carmen Juarez and Berthe Marte-Benavides, pled guilty to reduced misdemeanor charges and were sentenced to probation for two years. Ariz. Republic, Feb. 13, 1985, § Al, at 14, col. 6. On October 18, 1985, defendant Katherine Flaherty also pled guilty to a misdemeanor charge and received a similar probation sentence. Ariz. Daily Star, Oct. 19, 1985. Telephone interview with Defense counsel Ellen Yaroshefsky, counsel for Wendy Lewin (June 27, 1986).

Among the 11 defendants tried in Aguilar were Reverend John Fife and Jim Corbett, recognized co-founders of the sanctuary movement; Father Tony Clark; Father Quinones; Sister Darlene Nicgorski; Philip Conger, director of the Tucson Ecumenical Council; Mary K. Doan Espinoza, coordinator of religious education at Sacred Heart Church in Nogales, Arizona; Peggy Hutchinson, director of border ministry for the Tucson Metropolitan Ministry; and church workers Wendy Lewin, Maria del Socorro Pedro de Aguilar, and Nena McDonald. See Kemper, Convicted of the Gospel, SOJOURnER, July 1986, at 14-20.

232. When the indictments were returned in January, 1985, almost 200 churches and 
refuge for Central American people fleeing persecution, particularly from the countries of El Salvador and Guatemala. ${ }^{233}$

In Aguilar, the government's broad pretrial motion urged the court to preclude four entire defenses and related evidence. ${ }^{234}$ The government attempted to prevent defendants from forming a defense based either upon the Refugee Act of 1980, international law, freedom of religion, the absence of criminal intent, or the law of necessity. ${ }^{235}$

The government had a sound basis for surmising that these defenses might be relied upon by the defendants in Aguilar. In March, 1984, the government had infiltrated the sanctuary movement with informants ${ }^{236}$ who attended meetings at which the 1980 Refugee Act and international law were discussed as the legal basis to justify sanctuary activities. At these meetings, the defendants affirmed their commitment to assist the Salvadorans and Guatemalans, whom the defendants believed were entitled to refugee status under these laws, despite the prevailing INS policy. ${ }^{237}$ The government also obtained written materials setting forth the legal defenses available to the sanctuary workers

synagogues, and 11 cities, were openly defying U.S. immigration laws and providing sanctuary for Central Americans. Currently, about 380 congregations involving about 70,000 workers, 22 cities, 20 universities, and two states serve as sanctuaries. R. GoLDEN \& M. MCCoNNELL, Sanctuary, The New Underground RaIlroad 49-54 (1986); Conversation with M. McConnell, author (Jan. 5, 1987). For a historical background and religious underpinning of the sanctuary movement, see Colbert, Motion in Limine: Trial Without Jury, A Government's Weapon Against the Sanctuary Movement, 16 HoFstra L. REv. 1 (1987).

233. See Colbert, supra note 232, at 20-34 (reviewing human rights violations in Guatemala and El Salvador).

234. In addition to the enumerated defenses, the government's motion in limine also sought to bar the defense and its witnesses from "testifying about, alluding to, or presenting any evidence, either directly or indirectly ... on the following issues or subjects": (1) reference to the unindicted Salvadoran and Guatemalan co-conspirators as "refugees" or "asylees"; (2) the immorality of the United States government's Central American policy and possible U.S. violations of international law; (3) any alleged episodes, stories or tales of civil strife in Central America; (4) past and present U.S. policy regarding the granting or denial of asylum or refugee status to aliens from Central America and from other countries; (5) the impact that a guilty verdict would have upon the immigration status of the unindicted coconspirators; and (6) the policy of amnesty and extended voluntary departure for Salvadorans. Government's Motion in Limine at 2-3, Aguilar (No. CR-85-008-PHX-EHC).

235. Id. at $1-2$.

236. In March 1984, the government launched "Operation Sojourner" and placed two informants within the sanctuary movement. The informants were present at, and recorded, legal meetings attended by some of the sanctuary defendants. Agent Urged Caution in Taking on "Frito Bandito" Railroad, Tucson Gazette, June 30, 1985, at x, col. 2.

237. The approval rate for Salvadorans seeking political asylum between 1979 and 1984 was less than $3 \%$. In 1983 and 1984, less than $1 \%$ of Guatemalans applying were granted asylum. See 21 HARv. C.R.-C.L. L. Rev. 495, 529 n.150 (1986); N.Y. Times, Feb. 3, 1985, § 1, at 30, col. 1; St. Raymond's Social Justice Committee, Central American Refugee Report, May 1984, at 2, 6; Comment, Salvadoran Illegal Aliens: A Struggle to Obtain Refuge in the United States, 47 U. PrtT. L. Rev. 295, 299 (1985); Helton, Second Class Refugees, N.Y. Times, April 2, 1985, at A27, col. 2.

These figures should be compared to the approval rates during the same period for people fleeing countries with which the U.S. has unfriendly relations, or which it considers part of the communist bloc, such as Iran, 72\% in 1983 and $60 \%$ in 1984; Afghanistan, $82 \%$ in 1983 and $41 \%$ in 1984; and Poland, over $30 \%$ in 1983 and 1984. St. Raymond's Social Justice Committee, Central American Refugee Report, May 1984, at 2. 
when it searched and recovered documents from the home of one of the defendants. ${ }^{238}$ The government's memorandum of law indicated that its motion in limine was based on media statements of three of the defendants and on defenses used in similar immigration cases. ${ }^{239}$

The Aguilar case illuminates many of the competing arguments faced by a trial court when a government's motion in limine to exclude a defense is presented for judicial review prior to trial. The government's supporting memorandum asked the court to invoke its inherent and statutory power to manage a criminal trial in order to preclude "the parading of potentially prejudicial and irrelevant matters before the jury."240 While never explicitly explaining the prejudicial nature of each defense, the federal prosecutors instead focused on the potential consequences of denial of their motion. They argued that the courtroom would become "an arena to put U.S. Central American policy on trial," 241 and that the trial itself would be converted into "a political stage to advance the defendant's symposium on Central American conflicts."242 The government's memorandum suggested that the granting of the motion would avoid "extensive [trial] delay and extensive judicial involvement" 243 in deciding "complex" 244 issues during trial, while avoiding the risk that the trial would damage the "dignity and decorum of the courtroom." 245

The defense countered by asserting that the government's motion in limine was unanswerable and should be dismissed because it was

238. The government conducted a search of defendant Sister Darlene Nicgorski's apartment shortly after the indictment was returned against her, and recovered recorded minutes of a 2-day meeting held in 1984 in Tucson. At the meetings, attorneys and sanctuary workers discussed various possible legal strategies in cases of sanctuary defendants. The government also recovered a memorandum written by the Chicago Religious Task Force which discussed possible courtroom strategies to promote the objectives of the sanctuary movement. These documents were included in the government's supplemental memorandum in support of its motion in limine. Memorandum in Response to Defendant's Motion to Strike the Government's Motion in Limine at 6-8, Aguilar (No. CR-85-008-PHX-EHC).

239. Id. at 11-12. The government's memorandum in support of its motion in limine stated that the Aguilar case was "not the first indictment involving persons in the 'underground railroad' movement." Government's Memorandum in Support of Motion in Limine at I, Aguilar (No. CR-85-008-PHX-EHC). At the time of the Aguilar indictment, one sanctuary worker, Stacy Merkt, had been convicted of transporting a Salvadoran couple and their baby within the United States in violation of 18 U.S.C. § 1324 (a)(2). United States v. Merkt, No. B84-746 (S.D. Tex. 1984), aff'd, 794 F.2d 950 (5th Cir. 1986), cert. denied, No. 86-1089, slip op. (Mar. 30, 1987). Another sanctuary case had been dismissed, United States v. Conger, No. CR-84-1016-TUC-ACM (D. Ariz. 1984), and two others wre pending, United States v. Elder, 601 F. Supp. 1574 (S.D. Tex. 1985) and United States v. Merkt, 764 F.2d 266 (5th Cir. 1985) (en banc). The government also attached copies of media articles to its memorandum in which defendants Fife, Corbett, and Conger were quoted.

240. Memorandum in Response to Defendants' Motion to Strike the Government's Motion in Limine, supra note 238, at 13.

241. Id. at 7 .

242. Id. at 15.

243. Id. at 14 .

244. Id. at 13.

245. Id. at 15 . 
overly broad, vague, and nonspecific. ${ }^{246}$ The defense contended that the accused's right to prepare and present a full defense was impaired when pretrial disclosure was required "before the defense has even developed its own theories." 247 It argued that a response to the government's motion on the merits would violate an accused's fundamental right to remain silent, to be presumed innocent, to be free from selfincrimination, and to insist that the government meets its burden, without defense assistance, of proving guilt. ${ }^{248}$ The defense viewed the government's motion as transforming the accused's right to be judged by a jury which has heard the defense evidence during trial into a motion for summary judgment decided by the court before trial.

Despite the court's granting of the government's motion in limine to preclude each of the four defenses from jury consideration, this ruling neither avoided the "extensive delay and judicial involvement" promised by the government in its memorandum, nor did it simplify the issues presented at trial. To begin, the pretrial motion practice lasted nine months and included over 150 motions, applications, and memoranda submitted by both parties ${ }^{249}$ before the court's final in limine ruling on October 25, 1986.250

Moreover, the trial judge's in limine order compromised the court's impartiality and improperly affected its evidentiary rulings during trial. When the court accepted the government's in limine arguments and precluded evidence of entire defenses from being heard by the jury, it lost all appearance of neutrality. At trial, the court made several questionable rulings on the proper scope of defense questioning on crossexamination.

For instance, the main government witness, informant Jesus Cruz, was permitted to testify that defendant Father Quinones had accepted one hundred dollars from a Salvadoran to help him cross the border. A jury could have inferred from this testimony that the defendant's mo-

246. Motion to Strike the Government's Motion in Limine at 4, Aguilar (No. CR-85-008PHX-EHC).

247. Id. at 17-18.

248. Id. at $3-4$.

249. The pretrial motion practice was voluminous. Beginning with the government's motion in limine and 31-page memorandum in support which accompanied the indictment, the parties served over 150 separate documents, including defendants' offers of proof on each of the proposed defenses. While not all of these applications and responses were concerned with the motion in limine (other motions concerned the use of informants, search and seizure issues, selective prosecution, and government misconduct), it is obvious that the litigation concerned with the court's in limine ruling caused extensive pretrial delay.

250. The court's final in limine ruling occurred during jury selection on October 25 , 1985 and was reduced to a written order just before trial commenced on October 28, 1985. The trial judge granted the government's motion and excluded the four defenses requested, stating that "no evidence will be received to prove necessity or duress, [or] of religious beliefs, [or] international law, [or on] lack of criminal intent." Court Order of Oct. 28, 1985, Aguilar. The court also precluded evidence of defendant's belief that the aliens involved were refugees. Finally, the court precluded any evidence to demonstrate that there was or is "a civil strike, lawlessness, or danger to civilians in any foreign country." Id. 
tive for sanctuary activity was pecuniary. Yet the court would not allow the defense to question Cruz about Father Quinones' religious beliefs as the basis for his actions because the in limine order precluded any reference to religion as a defense. ${ }^{251}$ Thus, the defense was not permitted to refute the jury's impression that the defendant's motive was financial self-interest, nor to show that his actions were religiously inspired.

According to defense counsel, the trial judge peremptorily interpreted his in limine pretrial ruling several other times during trial to restrict questions or evidence that the defense believed were relevant to establishing a reasonable doubt as to one of the elements of the crime. ${ }^{252}$ Some of the defendants, for example, were charged with encouraging or inducing illegal aliens to unlawfully enter this country. ${ }^{253}$ When a Central American witness for the prosecution was asked by defense counsel if a particular sanctuary defendant encouraged or induced her to enter the United States, the witness testified that it was the devastating conditions in her homeland that caused her to flee and to seek safety in this country, not the actions of any of the defendants. "No one encouraged me," she stated, "there is a war going on in my country." 254 The court struck the witness' answer as violative of the court's in limine ruling, which had precluded both a defense based upon necessity, and any references to the civil wars in El Salvador and Guatemala. ${ }^{255}$

The judge took the extraordinary measure of directing defense counsel to desist from asking any "open-ended" questions when crossexamining prosecution witnesses. He limited the inquiry in this area to leading questions only, requiring a "yes-no" answer. ${ }^{256}$ When one government witness, Salvadoran Alexandro Rodriguez, tried to answer a defense leading question and explain that his reasons were not the result of anyone's persuasion, but rather his own effort to gain temporary safety here, the trial judge stated: "I think people from Latin America perhaps have a difficulty in just answering the question 'yes' or 'no' by nature of their personal attitudes . . .."257

In addition, the use of certain words triggered an instant rebuke from the trial judge, according to defense counsel. ${ }^{258}$ The court's in limine ruling had precluded any defense based on the Refugee Act of

25I. Record at 4878, Aguilar (No. CR-85-008-PHX-EHC).

252. Conversations with defense attorneys Karen Snell, attorney for Maria del Socorro Pedro de Aguilar (Dec. 23, 1986); Nancy Postero, counsel for Mary Kay Espinosa (Sept. 5, 1986); Michael Altman, counsel for Sister Nicgorski (July 24, 1986); Ellen Yaroshefsky, counsel for Wendy Lewin (June 27, 1986).

253. 8 U.S.C. § 1324(a)(4) (1982).

254. Record, supra note 251 , at 6682 .

255. Id. at 6617; see notes 250,234 supra.

256. Record, supra note 251 , at $6416-17,6429,6447-48$.

257. Id. at 6335 .

258. Conversations with defense attorneys, supra note 252. 
1980.259 The judge apparently believed this ruling prevented the defense from referring to the Salvadoran and Guatemalan co-conspirators as refugees. The judge stated that such a reference was a legal conclusion, and directed the defense to refer to them as "aliens" as the prosecution had requested. ${ }^{260}$ The defense eventually was able to convince the judge that the term "aliens" was prejudicial, and was subsequently permitted to refer to the Central Americans as "people" or "Central American people." This was only one of many angry exchanges between the court and defense counsel related to the broad in limine ruling. ${ }^{261}$

The words "torture" and "killed" also drew a sharp response from the trial judge, who assumed that they were used to evoke images of the civil war, a tactic he had forbidden in his in limine ruling. ${ }^{262}$ Defendant Aguilar was charged with conspiracy to encourage or induce a 14-year old Salvadoran girl to cross the border unlawfully. ${ }^{263}$ The defense sought to establish that the 61-year-old defendant accompanied the girl across the border because of motherly concern that had developed while the girl was in an immigration detention cell in Mexico. Defense counsel tried to question the prosecution witness about the relationship, and elicited testimony that Ms. Aguilar had brought the girl food and had provided spiritual companionship during the period of incarceration. ${ }^{264}$ However, when the witness testified that the food brought by the defendant was necessary because the prison diet was too spicy and caused her lips to chap, the court interrupted and struck this response as being related to "conditions" and, therefore, within the in limine prohibition. ${ }^{265}$

While such rulings undoubtedly reflect an attempt by the trial judge

259. Refugee Act of 1980, Pub. L. No. 96-212, 94 Stat. 102 (1980) (codified at Immigration and Naturalizaton Act $\S \S 101(\mathrm{a})(42), 207-209,243(\mathrm{~h}), 411-414,8$ U.S.C. $\S 1254(\mathrm{a})(1)$ (1982)). The Refugee Act grants refugee status to:

any person who is outside any country of such person's nationality .... and who is unable or unwilling to return to, and is unable or unwilling to avail himself or herself of, the protection of that country because of persecution or a well-founded fear of persecution on account of race, religion, nationality, membership in a particular social group, or political opinion.

8 U.S.C. §1101(a)(42) (1982) (emphasis added).

In INS v. Stevic, 467 U.S. 407 (1984), the Supreme Court stated that parties must meet a higher standard of "clear probability" that the undocumented person would be subject to persecution, in order for the Attorney General to grant mandatory refugee status. 8 U.S.C. $\S 1253(\mathrm{~h})$ (1982). The "well-founded fear of persecution" standard applies only to the Attorney General's discretionary powers. 8 U.S.C. § 1158(a) (1982).

260. Record, supra note 251, at 5308-12.

261. See generally id. at 6417-50; Varn, Sanctuary Lawyer Accused of Attempt to Confuse Jurors, Ariz. Republic, Apr. 5, 1986, at B1, B4; Varn, Santuary Judge, Defense Lawyers Escalate Namecalling, Ariz. Republic, Mar. 7, 1986, at B1, B3; Varn, Judge Muzzling Truth, Defense Says in Sanctuary Trial, Ariz. Republic, Jan. 17, 1986, at B1, B8.

262. Record, supra note 251 , at $6416-17$.

263. See note 253 supra and accompanying text.

264. Record, supra note 251 , at 6761 .

265. Id. at 6762-71. 
to be consistent with his in limine ruling, they demonstrate the inherent difficulty involved when a court issues overly broad exclusionary orders before it has heard any evidence at trial or has become fully familiar with the case. Contrary to his ostensible goal of remaining independent by granting the government's motion in limine, the trial judge appeared to assume a more intrusive role into the jury's factfinding responsibilities during the trial. Further, rather than simplifying the issues at trial and promoting the "decorum and dignity of the courtroom," the motion in limine led to frequent verbal exchanges between the judge and defense counsel over complex legal and evidentiary issues related to the in limine ruling.

Not only did the granting of the government's in limine motion fail to produce the asserted benefits to courtroom efficiency and decorum, it also severely handicapped the defense. Perhaps more than any other ruling, the court's preclusion of a defense based on absence of specific intent paralyzed the defendants' opportunity to present a full response to the charges against them. ${ }^{266}$ Based on this ruling, the defendants could neither testify nor introduce evidence that their intent was not to engage in a criminal conspiracy to violate the immigration laws, but was in compliance with the Refugee Act of 1980 and with their understanding of international law. ${ }^{267}$

The government's pretrial motion also placed defendants at a severe disadvantage because it compelled them to anticipate early in their pretrial preparation whether they would rely upon each cited defense at trial. When it filed the motion in limine, the prosecution was considerably more familiar with the relevant facts and law than were the defense attorneys. The prosecutors had been working on the case since Operation Sojourner was launched in March, 1984. According to one of the defense counsel, the defendants might have persuaded the trial court to allow a necessity defense at trial if they had had time to prepare, and had been able to argue this ruling at trial. 268

It is not surprising that the trial judge in Aguilar, having donned an evidentiary straitjacket prior to trial, often faced difficult evidentiary rulings which not infrequently elicited Pavlovian-like refusals to reconsider defense testimony and interrogation into "forbidden" areas. Aguilar illustrates why the usual criminal trial procedure involves a

266. "This ruling totally impaired the defendants ability to present evidence related to negating the 'specific intent' element of the crime of conspiracy." Telephone conversation with Karen Snell, defense counsel for Maria del Socorro Pedro de Aguilar (Jan. 5, 1987).

267. See Government's Motion in Limine, supra note 234, at 1-2.

268. Defense counsel focused on the necessity for Central American refugees to remain in the U.S., rather than the necessity for them to enter in the first place:

When people apply for political asylum in a third country, as is presently required by INS regulations, they are frequently returned to their own country before the asylum process is completed. We just didn't appreciate fully the parameters of the necessity defense, and the factual support we had for that defense, at the time we argued the government's motion in limine.

Telephone conversation with Karen Snell, supra note 266. 
court issuing such rulings during trial after familiarizing itself with the issues in the case. There is simply no way a judge can anticipate the many ways in which a pretrial ruling to exclude a defense may affect the propriety of trial rulings and the fairness of the trial procedure itself.

The use of a motion in limine to exclude an entire defense poses serious threats to an accused's right to a fair trial. In the following section, I discuss the motion's effect on the individual's constitutional rights in a criminal case in general. I then analyze how the government's broad motion in limine in a politically sensitive trial threatens to undermine one of the constitutional bedrocks of our legal system-the right to trial by jury.

\section{The Accused's Constitutional Rights}

The prosecutor's recent expanded use of the motion in limine to exclude an entire defense threatens traditional concepts of criminal trial practice. When the court requires the defense to respond to the government's filing of such a motion, it has already skewed the scales of justice by providing the prosecution with information on the defendant's case in advance of trial and consequently lightening the prosecution's burden of proof at trial. At the same time, the requirement of answering to this motion subverts three crucial rights of criminal defendants: the right against self-incrimination, the right to remain silent, and the right to be presumed innocent. When such motions are granted, a defendant's right to present a full defense becomes severely compromised. And in the context of trial by jury, the effect of granting such a motion may be to remove the determination of guilt or innocence from the jury's hands.

\section{A. The Government's Prosecutorial Duty Versus the Accused's Fifth Amendment Rights}

As noted above, the filing of this pretrial motion, unless dismissed by the trial court at the outset, facilitates the government's meeting its burden of proof. ${ }^{269}$ Even if the trial court ultimately denies the government's motion, by requiring the defense to respond, the court compels a pretrial preview of defense theories. In answering the motion, the defendants must present legal and factual arguments in sufficient detail to persuade the court to allow evidence of the disputed defense to be introduced at trial. Inevitably, the accused is compelled to divulge her trial strategy, allowing the prosecution to shore up weaknesses in its direct case and to prepare rebuttal of defense contentions. Thus, the prosecution's motion in limine requires defense counsel to disclose her

269. In an adversarial system, the prosecuting counsel is expected to anticipate an opponent's strategy but is not permitted to formally learn the specific defense strategy. This form of pretrial discovery of defense theories is formally permitted for only two specific defenses, alibi and insanity, in the Federal Rules of Criminal Procedure. FED. R. CRIM. P. 12.1, 12.2. 
"ideas, thoughts and strategies"270_-information that the Supreme Court considers privileged and whose confidentiality is recognized as vital to the proper functioning of the criminal justice system. ${ }^{271}$

The filing of a motion in limine in a criminal trial also infringes upon a defendant's rights to remain silent and to avoid self-incrimination. ${ }^{272}$ When courts allow them, such motions compel the accused to speak on her own behalf-or else risk waiving an entire defense. The accused can no longer rely upon absolute constitutional protections; to fully enjoy the rights to be silent and to be presumed innocent, an accused must first satisfy a threshold requirement. In attempting to satisfy this initial test, the accused foregoes these fundamental rights without any proof of guilt by the prosecution.

When a court allows such motions, it jeopardizes an accused's constitutional rights and undeniably shifts the traditional balance of criminal justice to the great benefit of the prosecutor. In the process, the government's power to prosecute and to deny citizens their freedom is gravely expanded. For these reasons, traditional notions of justice require that a trial court, faced with a government motion in limine, hold the government to a high standard before compelling the defense to respond. The court must require that the government establish 1) the basis for asserting that the accused intends to use a specific defense; and 2) the potential prejudicial effect of presenting the defense at trial. A court must not permit the mere filing of the motion to compel the defense to respond.

\section{B. The Accused's Sixth Amendment Rights to a Jury Trial and to Present a Defense}

When a court grants a motion in limine and precludes a legally recognized defense in advance of trial, it also jeopardizes the accused's "inherent and invaluable right" to be judged by a jury that has had the opportunity to hear and consider a complete defense to the charge. ${ }^{273}$ Such rulings occur before the defendant has decided whether or not to even present a defense, much less how she will attempt to establish the elements of that defense. Almost every in limine ruling to exclude an entire defense requires the court to prematurely determine the propriety of a defense at a pretrial stage, without having heard any witness'

270. Hickman v. Taylor, 329 U.S. 495, 511 (1947).

271. United States v. Nobles, 422 U.S. 225, 238 (1974).

272. Supreme Court rulings have preserved, and elaborated on, this jurisprudential balance between the government's prosecutorial duties and the individual's fifth amendment rights. See, e.g., Miranda v. Arizona, 384 U.S. 436 (1966) (suspect in a criminal investigation or individual taken into police custody must first be informed of her rights to remain silent and to consult with a lawyer, before being questioned by law enforcement officials).

273. Duncan v. Louisiana, 391 U.S. 145, 152 (1968) (referring to a resolution adopted by the First Congress of the American Colonies (the Stamp Act Congress) on October 19, 1765 , declaring " $[t]$ hat trial by jury is the inherent and invaluable right of every British subject in these colonies"). 
testimony. Even when requested to rule on a pure question of law, the court's unfamiliarity with the case heightens the possibility that its in limine ruling will infringe upon the jury's role as factfinder. ${ }^{274}$ In so doing, the court denigrates the jury's role in the criminal justice system.

In 1968, in Duncan v. Louisiana, ${ }^{275}$ the United States Supreme Court commented: "Fear of unchecked power ... found expression in the criminal law in this insistence upon community participation in the determination of guilt or innocence."276 Two years later, the Court elaborated: "[T] he essential feature of a jury obviously lies in the interposition between the accused and his accuser of the commonsense judgment of a group of laymen, and in the community participation and shared responsibility that results from that group's determination of guilt or innocence." 277

It is this "community participation" in judging the facts of a case which has led one commentator to describe the right to trial by jury as "more than an instrument of justice and more than one wheel of the constitution: it is the lamp that shows that freedom lives."278 When citizens assume the role of jurors in a criminal trial, they are empowered to judge collectively the fate of another individual. The deliberation process requires that jurors reveal and openly discuss the basis of their opinions. Others may challenge and disagree with a juror's thinking, but the process itself-an open dialogue in which all participate and contribute their ideas-explains why juries are, in the truest sense, the democratic backbone of the criminal justice system.

The government's motion in limine to preclude an entire defense directly challenges the jury's role, as envisioned by the Framers of the Constitution, as a democratic body. ${ }^{279}$ This role is all the more impor-

274. See notes 251-265 supra and accompanying text.

275. 391 U.S. 145 (1968).

276. Id. at 156.

277. Williams v. Florida, 399 U.S. 78, 100 (1970).

278. P. Devlin, Trial By Jury 164 (1956).

279. For examples of articles describing the jury's role as a democratic body, see Howe, Juries as Judges of Criminal Law, 52 HARV. L. REv. 582 (1939); Kunstler, Jury Nullification in Conscience Cases, 10 VA. J. INT'L L. 71 (1969); Sax, Conscience \& Anarchy: The Prosecution of War Resisters, 57 Yale Rev. 481 (1968); Scheflin, Jury Nullification: The Right to Say No, 45 S. CaL. L. Rev. 168, 185-93, 207-15 (1972); Scheflin \& Van Dyke, Jury Nullification: The Contours of a Controversy, Law And Contemp. Probs., Autumn 1980, at 51; Sperlich, Trial By Jury: It May Have a Future, 1978 Sup. CT. REv. 191, 193 n.10; Van Dyke, The Jury as a Political Institution, 16 CATH. LAw. 224 (1970).

Professor Scheflin argues that a jury has the right to acquit criminal defendants on the basis of conscience, even when the accused is technically guilty based on the law and relevant facts. Scheflin states that this right of "nullification" is derived from the jury's role "as a popular check on government tyranny and judicial servility." Scheflin, supra, at 172. He cites one commentator who believes that " "jury nullification is a kind of repository of grass roots democracy' since ordinary citizens can effectively say no to their rulers when their policies and laws are no longer in touch with the will of the people." Id. at 187 (citing L. VELVEL, UNdeclared War and Civil Disobedience 215 (1970)).

In this article, I am advocating that a jury's verdict should be based not on conscience, but rather on the court's legal instructions concerning a legally recognized defense. I argue that precluding a legally recognized defense before trial violates the jury's role as independ- 
tant in politically sensitive cases, where the defendant's only opportunity to be judged fairly depends on a jury gaining sufficient understanding of the circumstances leading to the accused's arrest. Political dissidents are often portrayed as threats to national security or as dangerous extremists seeking to overthrow the system, making full knowledge of the truth all the more crucial as the defense attempts to overcome the juror's alarm. To prevent juries from serving as a rubber stamp, and to preserve their role as an important "bulwark against official tyranny," 280 courts must carefully scrutinize the government's motions in limine to assure that they do not prevent an accused from presenting a full defense to the jury members who will pass judgment.

Juries are not always able to remain above collusion in government abuse of democratic processes. They tend to follow the political trends of the times. During World War I, members of the International Workers of the World, better known as "Wobblies," were successfully prosecuted for their labor organizing activities, as were members of the Congress of Industrial Organization in the 1930s. ${ }^{281}$ State jurors did not hesitate to convict defendants who were known "anarchists" in the Sacco and Vanzetti trial, ${ }^{282}$ or labor organizers like Tom Mooney or Joe

ent factfinder, and consequently the accused's right to trial by jury. The court must permit an accused to attempt to establish the elements of a legally recognized defense. At the conclusion of trial, the court will instruct the jury on the appropriate law.

I recognize that prosecutors fear that a jury will "nullify" the law because of evidence which was presented and later ruled insufficient to establish a defense. Such concerns do not overcome the adverse consequences described in this article to an accused's right to present a legally accepted defense, and to be judged by a jury properly instructed in the law.

280. United States v. Dougherty, 473 F.2d 1113, 1131 n.33 (D.C. Cir. 1972).

281. During World War I and the "Red Scare," the political climate produced a host of antilabor, anticommunist, and antisedition laws. In June 1917, a federal conspiracy Espionage Act was passed, ch. 30, 40 Stat. 217 (1917) (codified as amended at 18 U.S.C. $\$ \S 792-$ 799 (1982)), followed by the Sedition Act in 1918, which provided for prison sentences of up to twenty years for anyone who:

[S]hall willfully utter, print, write, or publish any disloyal, profane, scurrilous, or abusive language ... or any language intended to bring the form of government of the United States, or the Constitution ... or the military or naval forces . . . or the flag ... or the uniform of the Army or Navy . . . into contempt, scorn, contumely, or disrepute, ....

Sedition Act, ch. 75, 40 Stat. 553 (1918). Over 2,000 criminal prosecutions were initiated charging, in most cases, individuals who expressed opinions opposing the United States' entry into World War I. See Z. Chaffee, Free Speech in the United States 38-41, 51 (1941). In addition, during this period, Attorney General Palmer ordered nationwide raids on aliens who were charged with being members of the Communist Party or the Communist Labor Party, resulting in the arrest of 4,000 people. See id. at 196; I N. Dorsen, P. BENDER \& B. Neuborne, Emerson, Haber and Dorsen's Polrtical and Civil Rights in the United States 44 (4th ed. 1976). Many states enacted their own criminal anarchy, criminal syndicalism, and antisedition laws, aimed primarily at members of the International Workers of the World (I.W.W.) and the Non-Partisan League, responsible for approximately 1,400 state arrests from 1919-1920. R. Murray, Red Scare: A Study of National Hysteria, 1919-1920, at 23335 (1955). See also W. Preston, Aliens and Dissenters and Federal Suppression of RadiCALS, 1903-1933, chapters vii-ix (1963).

282. Commonwealth v. Sacco, 255 Mass. 369, 151 N.E. 839 (1926). The Sacco and Vanzetti trial has been the subject of critical debate among historical scholars. See F. Frankfurter, The Case of Sacco and Vanzetti (1927); R. Strauss Feuerlicht, Justice 
Hill. ${ }^{283}$ During the post World War II period, a new wave of "Red Scare" trials appeared, including the spy trial of Julius and Ethel Rosenberg ${ }^{284}$ and the Smith Act cases, ${ }^{285}$ which prosecuted members of the Communist Party. Juries were sufficiently caught up in the Cold War hysteria of the period to have little difficulty returning convictions in these cases, despite the questionable validity of their verdicts.

However, the power of the citizenry, exercised directly and mean-

Crucified: The Story of Sacco and Vanzetti (1977); W. Young \& D. Kaiser, Postmortem: New Evidence in the CaSe of Sacco and Vanzetti (1985).

283. See, e.g., R. Boyer \& H. Morais, Labor's Untold Story, United Electrical Radio and Machine Workers of America 172, 196 (1955); R. Frost, The Mooney Case (1968); E. Hopkins, What Happened in the Mooney Case (1932); H. Hunt, The Case of Thomas J. MOONEY AND WARREN K. BILLINGS (1929).

284. United States v. Rosenberg, 195 F.2d 583 (2d. Cir. 1952), cert. denied, 344 U.S. 838 (1952); see also Rosenberg v. United States, 346 U.S. 273 (1953) (Douglas, J., vacating stay of execution); United States v. Rosenberg, 109 F. Supp. 108 (S.D.N.Y. 1953) (denying motion to reduce death sentences); United States v. Rosenberg, 108 F. Supp. 798 (S.D.N.Y. 1952) (denying petition to set aside conviction and sentence), aff'd, 200 F.2d 666 (2d Cir. 1952), cert. denied, 345 U.S. 965 (1953). For critical reviews of The Rosenbergs' conviction and sentence, see W. SchneIR, Invitation to an Inquest (rev. ed. 1983) and Markowitz \& Meerepol, The "Crime of the Century" Revisited: David Greenglass' Scientific Evidence in the Rosenberg Case, 44 Scr. \&. Soc'y 1 (1980); cf. R. Radosh \& J. Milton, The Rosenberg File: A Search for the Truth (1983), and the Rosenbergs' sons' rebuttal, R. \& M. MEEREPOL, WE ARE Your Sons (1975).

285. 18 U.S.C. $\$ \S 2385,2387$ (1982). The Smith Act was passed as Title I of the Alien Registration Act, ch. 439, 54 Stat. 670 (1940). It targeted any individual who

(1) knowingly or willfully advocate[s], abet[s], advise[s], or teach[es] the duty, necessity, desirability, or propriety of overthrowing or destroying any government in the United States ...; ; or (2), with the intent to cause the overthrow or destruction of any government, print[s], publish[es], edit[s], issue[s], circulate[s], sell[s], distribute[s], or publicly display[s] any written or printed matter advocating, advising, or teaching the duty, necessity, desirability, or propriety of overthrowing or destroying any government in the United States by force or violence or attempts to do so; or (3) . . . organize[s] or help[s] to organize any society, group, or assembly of persons who teach, advocate or encourage the overthrow or destruction of any government in the United States by force or violence ... shall . . . be . . . imprisoned for not more than ten years.

In July, 1948, the government indicted 12 members of the Central Committee of the Communist Party of the United States for conspiracy under Sections 2 and 3 of the Smith Act. See United States v. Dennis, 341 U.S. 494 (1951); T. Emerson, D. Haber \& N. Dorsen, PolrtICAL and Civil Rights in the Unired States 100 (Students ed. 1967). After obtaining convictions in Dennis, the government initiated 15 similar prosecutions, indicting 121 defendants under the conspiracy provision of the Smith Act and eight others under the membership provision. Of these, 103 were convicted as conspirators and four others for belonging to the Communist Party. Juries acquitted only five individuals accused of conspiracy; charges against four others were dismissed by the court. The remaining defendants had not yet been brought to trial six years later when the Supreme Court decided Yates v. United States, 354 U.S. 298 (1957). See 1 N. Dorsen, P. Bender \& B. Neuborne, supra note 281, at 114.

In Yates, the Court reversed trial convictions in one of the Smith Act prosecutions, stating that mere advocacy and teaching of communist theory, without an actual call to violence, was insufficient proof under the statute. After Yates, the government stated it was unable to meet the Yates standards of proof, and the court dismissed charges against the defendants. No new criminal prosecutions were initiated, and all pending cases were dismissed but for one membership case. See id. at 121.

For examples of books written about the Smith Act trials, see K. O'ReILLY, Hoover AND the Unamericans: The FBI, Hoover and the Red Menace (1983); P. Steinberg, The Great "Red Menace": United States Prosecution of American Communists, 1947-1957 (1984); Beyond the Hiss Case: The FBI, Congress and the Cold War (A. Theoharis ed. 1982). 
ingfully through juries, is an additional safety check in our multibranched checks and balances system of democracy. The jury is the branch least susceptible to corruption and the one most likely to be objective, when educated and informed, for it lacks any direct vested interest in political trials of government dissidents.

The government's use of the broad motion in limine also demonstrates a lack of confidence in the ability of trial judges to make appropriate rulings during trial and to control court proceedings. In every criminal trial, the presiding judge must make a series of evidentiary rulings when a party objects to arguably inadmissible lines of inquiry. ${ }^{286}$ If an improper question is asked or improper testimony elicited, the judge can strike the impermissible material and direct counsel to cease that line of questioning.

Finally, the government's broad use of the motion in limine bypasses the usual judicial evidentiary rulings ${ }^{287}$ to limit improper evidence from jury consideration. The motion reduces the presiding judge to an enforcer of a pretrial order which restricts evidence from being heard, rather than a neutral magistrate who makes evidentiary rulings as the relevance of evidence becomes clearer. The government's attempt to justify the in limine practice as one which saves scarce judicial resources is dubious, at best. ${ }^{288}$ Even if the motion did save judicial resources, the consequences to the accused's right to a fair trial would greatly outweigh this purported justification.

Likewise, the government's admonitions that the court will not be able to control the proceedings should not be given great weight. In Aguilar, the government warned of possible disruptive behavior by the sanctuary defendants and counsel during trial unless the court granted its motion and established evidentiary parameters at the outset. ${ }^{289}$ Such arguments demonstrate a lack of confidence in the judiciary's ability to maintain proper decorum within the courtroom. They are remi-

286. Fed. R. CRIM. P. 401-403.

287. Prosecutors may use other trial procedures to prevent the use of a defense which they consider impermissible, such as requesting sidebar conferences, insisting upon defense offers of proof out of the jury's presence, and relying upon the court's rulings and instructions to the jury. The government's motion in limine is appropriate only when the prosecutor anticipates that the defense will be introducing prejudicial items of evidence and seeks the preclusion of such items pretrial. When used to preclude on entire defense, the motion in limine significantly jeopardizes an accused's right to a fair trial and should generally be dismissed by the trial court without requiring the defense to respond.

There are two narrow exceptions. A motion in limine is appropriate when the prosecutor claims that pretrial notice of an insanity or alibi defense has not been timely served, since both of these defenses have statutory notice requirements. FED. R. CRIM. P. 12.1-12.2. When the defense notifies the prosecution that it intends to use an insanity defense based upon a "mental disease or defect" which has been specifically rejected as such by an appellate court in the trial court's jurisdiction (e.g., compulsive gambling), a pretrial motion to exclude that defense might also be appropriate. See notes 132-133 supra.

288. See notes 181-198, 249-250 supra and accompanying texts.

289. Memorandum in Response to Defendant's Motion to Strike the Government's Motion in Limine at 7, 15, Aguilar (No. CR-85-008-PHX-EHC). 
niscent of arguments raised during the 1969 Chicago Seven conspiracy trial $^{290}$ - a case in which the defense attempted to invoke the independent role of the jury during jury selection. ${ }^{291}$

The motion in limine, when used to preclude entire defenses, also undermines the historical purpose of trial by jury. The right to a jury trial in a criminal case is rooted in the Magna Carta and in earlier English law. ${ }^{292}$ In Duncan v. Louisiana, ${ }^{293}$ the United States Supreme Court expressed its respect for the jury's historic role in our democracy:

A right to a jury trial is granted to criminal defendants in order to prevent oppression by the government. Those who wrote our Constitution knew from history and experience that it was necessary to protect against unfounded criminal charges brought to eliminate enemies and against judges too responsive to the voice of higher authority. ... Providing an accused with the right to be tried by a jury of his peers gave him an inestimable safeguard against the corrupt or overzealous prosecutor and against the compliant, biased, or eccentric judge. ${ }^{294}$

The jury, the Court concluded, is "fundamental to the American scheme of justice." 295

Far from being an inappropriate forum for politically sensitive debate, the jury's historic role has been to judge the law as well as the

290. United States v. Dellinger, 472 F.2d 340 (7th Cir. 1972), cert. denied, 410 U.S. 970 (1973). In the Chicago Seven trial, five leaders of the Anti-War Movement-David Dellinger, Rennie Davis, Tom Hayden, Abbie Hoffman, and Jerry Rubin-were convicted of violating the Anti-Riot Act of 1968, Pub. L. No. 90-284, 82 Stat. 75 (codified as amended at 18 U.S.C. $\S 2101$ (1982)). The Seventh Circuit reversed on appeal, based on the limited questioning allowed the defense during voir dire, and on improper judicial and prosecutorial demeanor during the trial. See also note 291 infra.

291. In the spring of 1968, thousands of protesters gathered in Chicago during the Democratic Convention and engaged in a series of street demonstrations to register their opposition to government policy. The Chicago police engaged in several violent incidents with the protesters, which received nationwide television coverage. Following the election of Richard Nixon in November, the Justice Department indicted eight leaders of the antiwar and civil rights movements and charged each with crossing state lines to initiate a riot. The trial became known as the Chicago Seven Trial when the court severed the trial of the eighth defendant, Black Panther Bobby Seale, after he had been gagged and bound in the courtroom. Dellinger, 472 F.2d at 368-70. See generally The Conspiracy TRIAL (J. Clavir \& J. Spitzer eds. 1970); J. Epstein, The Great Conspiracy Trial (1971); M. Ferber \& S. Lynd, The Resistance (1971); accord United States v. Berrigan, 283 F. Supp. 336 (D. Md. 1968) (preventing defendants from raising the issue of the jury's right to be instructed that it had the power to return a verdict consistent with the consciences of its members), aff'd sub nom. United States v. Moylan, 417 F.2d 1002 (4th Cir. 1969).

292. See Duncan v. Louisiana, 391 U.S. 145, 145 (1968) (referring to the Magna Carta as the source of the trial by jury); Thompson v. Utah, 170 U.S. 343 (1898) (semble). "No free man shall be taken or imprisoned or [dispossessed] or outlawed or exiled or in any way destroyed ... except by the lawful judgment of his peers and the law of the land." Magna Carta, 17 John ch. 39 (1215). Roscoe Pound believed the institution originated several hundred years earlier in continental proceedings related to land holdings and taxation, and eventually appeared in England at about the time of William I. See Rooks, Sources of Trial by Jury in America, Trial 46-49 nn.1-2 (Sept. 1983) (citing Pound, Jury, 8 Encycl. Soc. Scr. 492-93 (1932)).

293. 391 U.S. 145 (1968).

294. Id. at 155-56.

295. Id. at 149. 
facts. The jury's independence served as a valuable check on government abuse of individual rights and freedoms. One commentator has noted that such legal determination through the hands of the jury was "in harmony with our basic concepts of a democratic society and representative government." 296

Early case law reflected these sentiments. In a 1670 English case, ${ }^{297}$ for example, William Penn and William Mead were indicted for preaching before an unlawful assembly. The court directed that the jury convict the defendants based upon the uncontroverted evidence that the defendants were speaking to a group gathered at a church. The jury refused to do so even after the judges told each juror that:

you shall not be dismissed until we have a verdict that the court will accept; and you shall be locked up, without meat, drink, fire and tobacco; you shall not think thus to abuse the court; we will have a verdict by the help of God, or you shall starve for it. ${ }^{298}$

Despite actually being locked up for two days without food or water, the jury voted to acquit both defendants. The trial court held each juror in contempt for disobeying its order, fining each " 40 marks a man, and imprisonment till paid." 299 However, upon a writ of habeas corpus, this punishment of juries for their verdicts was overturned and abolished by the Court of Common Pleas, which affirmed that it is the jury who "determine[s] the law in all matters." 300

The jury's independent role as judge of the law was also affirmed in a case in colonial New York in 1736, when a trial jury refused to convict John Peter Zenger of seditious libel. ${ }^{301}$ Zenger was the only printer in New York who dared to publish stories exposing government corruption without first obtaining authorization from the British mayor as required by law. ${ }^{302}$ At the close of Zenger's trial, the court charged the jury that the King's prosecutor need only establish the fact of publication, already conceded by the defendant, since truth was not a recognized defense. The court, however, permitted Zenger's lawyer to argue that the jury's power included "the right beyond all dispute to determine both the law and the facts." 303 Zenger was subsequently acquit-

296. Scheflin, supra note 279 , at 188 (quoting Glasser v. United States, 315 U.S. 60,85 (1942)). The modern parallel to this historical role of the jury is discussed at notes 277-280 supra.

297. Penn \& Meade's Case, 6 Howell's State Trials 951 (1670); see also J. Mark, The Trial of William Penn 35, 36, 49, 50, adapted from J. Mark, VignetTes of Legal History (1965); Scheflin, supra note 279, at 170-72.

298. Penn \& Meade's Case, 6 Howell's State Trials, supra note 297, at 963.

299. Id. at 967-68.

300. Bushell's Case, 6 Howell's State Trials, supra note 297, at 999, 1015-16 (1670).

301. See The Tree of Liberty 29-31 (N. Kittrie \& E. Wedlock eds. 1986) (referring to J. Alexander, A Brief Narrattve of the Case and Trial of John Peter Zenger (1st ed. 1963)).

302. See id. at 31; Scheflin, supra note 279 , at 173.

303. See J. Alexander, supra note 301, at 78. 
ted in a case foreshadowing the principles underlying freedom of the press.

Juries acted "as a mainstay of liberty" 304 in several other politically sensitive cases both before and after the adoption of the Constitution. ${ }^{305}$ Colonial juries, for instance, refused to enforce the Navigation Acts, which required that all colonial trade pass through England. These jury verdicts resulted in the release of ships that had been impounded by British authorities in violation of the law.

The passage of the notorious Sedition Act in 1798 included a provision which affirmed the jury's "right to determine the law and the fact, under the direction of the court, as in other cases."306 Two years later, in a treason trial, the presiding judge included a similar jury instruction acknowledging the jurors' duty in this regard. ${ }^{307}$ Ironically, this same Justice, Samuel Chase, later faced impeachment proceedings, including one charge that he had usurped the jury function in other cases by denying them the right to decide the law. ${ }^{308}$ In the nineteenth century, jurors also exercised their power as judges of the law and acquitted defendants accused of violating unjust laws, such as the Embargo Act of 1808 and the Fugitive Slave Law of $1850 .{ }^{309}$

Thus, juries historically assumed an integral role as the citizenry's check on the executive, legislative, and judicial branches of government in order to prevent the exercise of power in conflict with basic constitutional freedoms. In 1895, however, the Supreme Court eliminated the

304. The Changing Role of the Jury in the Nineteenth Century, 74 YALE L. J. 170, 192 (1964) (student author).

305. See Rooks, supra note 292, at 4 . The colonial jury's refusal to follow the British Navigation Laws led to the enactment of the Stamp Act in 1765, which provided that jurisdiction over these cases would vest in the admiralty courts, where reliable judges appointed by the Crown sat without juries. See Scheflin \& Van Dyke, supra note 279. This intrusion into the colonists' jury rights became one of the grievances leading to the American Revolution. Id. at 57 n.20.

306. Ch. 74, 1 Stat. 596 (1798) (expired 1801). The Alien and Sedition Acts were passed in 1798, when the United States appeared on the verge of war with France. The statute was aimed at the Republican press, which was highly critical of the Federalist Presidency. The statute provided, in part, that

any person [who] shall write, print, utter or publish ... any false, scandalous and malicious writing ... against the government of the United States, or either house of the Congress ... or the President of the United States with intent to defame ... or to excite against them ... the hatred of the good people ... or to stir up sedition within the United States ... for opposing or resisting any law . . . or to aid . . . any hostile designs of any foreign nation against the United States ... shall be punished by a fine $\ldots$ and imprisonment not exceeding two years.

Criminal prosecutions were brought against the four leading Republican newspapers, involving 25 individuals and 15 indictments. See 1 N. DORSEN, P. BENDER \& B. NeUBORNE, supra note 281 , at $25-28$.

307. Case of Fries, 9 F. Cas. 924, 930 (C.C.D. Pa. 1800) (No. 5127).

308. See Scheflin, supra note 279 , at 176 .

309. See id. at 176-77; Sax, supra note 279; Fugitive Slave Act, ch. 60, 9 Stat. 462 (1850) ("An Act respecting fugitives from justice, and persons escaping from the service of their masters."); Embargo Act, ch. 66, 2 Stat. 499 (1808) ("An Act laying an embargo on all ships and vessels in the ports and harbors of the United States."), repealed ch. 5, 2 Stat. 506 (1809). 
jury's role as judge of the law in Sparf $v$. United States. ${ }^{310}$ Not until the late 1960s were defense attorneys once again reminding juries of their traditional role as "the conscience of the community" 111 when evaluating the guilt or innocence of a criminal defendant who had challenged unpopular government policies.

During the 1960s, as political protest spread against the government's racial policy at home and its foreign policy in Vietnam, the Nixon Administration brought many criminal conspiracy prosecutions against members of civil rights and anti-war movements. Though certainly not the first time the government has prosecuted those who oppose its policies, the period beginning in the late 1960s and continuing to the mid-1970s represents one of the few contemporary periods when trial juries did not automatically accept the government's legal positions in politically sensitive cases. In a number of these highly publicized trials, the government failed to convict defendants who were openly opposed to official U.S. policy. ${ }^{312}$ Even where convictions were obtained, the trial aroused public support and understanding for the political dissidents' views. ${ }^{313}$

310. 156 U.S. 51 (1895).

311. The actual words "conscience of the community" were used in United States v. Spock, 416 F.2d 165, 182 (1st Cir. 1969), in which a First Circuit 3-judge panel reversed a trial conviction of four individuals for violating Section 12 of the Military Selective Services Act of 1967, 50 U.S.C. $\$ 462$ (a) app. (1982). On appeal, the court directed judgments of acquittal for Dr. Benjamin Spock and Michael Ferber, and ordered new trials for Reverend William Sloane Coffin, Jr. and Mitchell Goodman. The four had been convicted for counseling, aiding, and abetting draft evasion during the Vietnam War, after publishing a document entitled "A Call to Resist Illegitimate Authority" which urged resistance to the draft.

Similar language was also used by the defense attorneys in one of the first anti-Vietnam War protest cases in United States v. Berrigan, 417 F.2d 1002 (4th Cir. 1969), cert. denied, 397 U.S. 910 (1970). The Supreme Court used similar words in deciding a capital punishment case the previous year. See Witherspoon v. Illinois, 391 U.S. 510, 519 (1968).

312. Between 1969 and 1973 , a series of highly publicized state and federal conspiracy trials followed the Chicago Seven case, in which juries acquitted defendants protesting government foreign and domestic policy. Acquittals occurred in October 1969 in the case of the Oakland Seven, who engaged in a series of protests against the draft and the Vietnam War, see Scheflin, supra note 279, at 199-201, and in several cases involving members of the Black Panther Party in New York from 1969-1970 (the "New York 21"), in New Haven in 1971 (Bobby Seale and Erica Huggins), and in California in 1973 (Angela Davis). In addition, members of Vietnam Veterans Against the War were acquitted in a federal conspiracy trial in Florida in 1973 (the "Gainesville 7"); and religiously motivated antiwar activists were acquitted after destroying Selective Service files both in New Jersey (the "Camden 28"), see United States v. Anderson, 356 F. Supp. 1311 (D.N.J. 1973), and in Milwaukee (the "Milwaukee 14").

313. In addition to the conviction (and subsequent reversal) of the Catonsville Nine and of the five defendants in the Chicago Seven trial, see notes 290-291 supra, other criminal trials were conducted in which the defendants were convicted but their antiwar activities were highly publicized. See, e.g., United States v. Spock, 416 F.2d 165 (1st Cir. 1969); note 312 supra. In United States v. Berrigan, 482 F.2d 171 (3d Cir. 1973), which involved the "Harrisburg Eight," a jury failed to convict any of the defendants on the main charge of conspiracy to kidnap Presidential Advisor Henry Kissinger, to destroy the underground heating systems in Washington, D.C., and to unlawfully interfere with the Selective Service System. The jury did, however, convict the defendants, Father Philip Berrigan and Sister Elizabeth McAlister, of seven counts of unlawfully sending letters into and out of Lewisburg Federal Penitentiary "without knowledge and consent of the warden." On appeal, the Third Circuit reversed con- 
Under the Reagan administration, federal prosecutors' in limine motions have targeted specific defenses that would provide legal justification for the acts of those charged with protesting the government's nuclear policy at home and foreign policy abroad. When analyzing this current strategy in its historical context, a logical inference can be drawn that the government hopes to forestall public review of its policies and to eliminate the citizenry's check on governmental exercise of prosecutorial power against dissidents. In fact, this was almost the exact wording of the government's motions in United States v. Aguilar ${ }^{314}$ and United States $v$. Fox. ${ }^{315}$ The government's use of the broad motion in limine demonstrates a lack of trust and confidence in the people who serve as jurors. The motion attempts to restrict the factual basis for a decision by asking the court to prevent evidence from ever reaching the jury. Such tactics undermine the bond of trust that exists between the government and the people, and severely impairs the integrity of the jury system. Public confidence in the fairness of a criminal trial is diminished, and, most seriously, the democratic process is thwarted.

\section{Concluston}

"The strength of our democratic society lies in our adherence to constitutional guarantees of the rights of the people, including the right to a fair trial and the right to give testimony in one's own behalf." 316 The government's use of the motion in limine to exclude entire defenses in politically sensitive trials jeopardizes these and other constitutional protections by waging a direct assault on the accused's right to trial by jury. ${ }^{317}$ Consequently, the jury's role "as an indispensable protection against the possibility of government oppression" 318 and "as a safeguard against arbitrary law enforcement" 319 is gravely endangered by this government pretrial motion practice.

victions on six counts, leaving each defendant with a single conviction for violating the prison contraband statute, 18 U.S.C. $\$ 1791$ (1982).

314. See notes 241-242 supra and accompanying text.

315. See notes 182-184 supra and accompanying text.

316. State v. Brechon, 352 N.W.2d 745, 752 (Minn. 1984) (Wahl, J., concurring).

317. In recent years, the right to trial by jury has been limited by Supreme Court decisions which have held that nonunanimous guilty verdicts in noncapital cases do not violate either the fourteenth or sixth amendments. See Apodaca v. Oregon, 406 U.S. 404 (1972); Johnson v. Louisiana, 406 U.S. 356 (1972). The Supreme Court has also rejected the necessity of 12-member juries in state courts by concluding that 6-member juries satisfy the sixth amendment. See Williams v. Florida, 399 U.S. 78 (1970). But of. Ballew v. Georgia, 435 U.S. 223 (1978) (5-member juries found to violate the sixth and fourteenth amendments). The Court has also validated nonjury trials where the maximum prison sentence is not greater than six months, see Baldwin v. New York, 399 U.S. 66 (1970); see also Taylor v. Hayes, 418 U.S. 488 (1974), or three years probation or a $\$ 10,000$ fine, see Muniz v. Hoffman, 422 U.S. 454 (1975). An additional restriction on an accused's right to trial by jury has been the use of anonymous juries. See United States v. Barnes, 604 F.2d 121 (2d Cir. 1979), cert. denied, 446 U.S. 907 (1980).

318. Brown v. Louisiana, 447 U.S. 323,330 (1980) (plurality opinion).

319. Williams v. Florida, 399 U.S. 78, 87 (1970). 
The government's broad motion in limine is antidemocratic not only because it jeopardizes an accused's right to a fair trial, but also because it suppresses evidence concerning government policy that is essential to the cultivation of an informed citizenry. Rarely does an individual citizen exercise as powerful a governance role and check on prosecutorial exercise of power as she does when serving as a juror in a politically sensitive trial. Media coverage of such trials also provides a valuable channel of public information about government policies. When, however, a government's pretrial exclusionary motion denies an accused the opportunity to explain to a jury the justification for, and circumstances leading to, her allegedly criminal conduct, the community's right of access to information is undermined. James Madison eloquently described the danger posed to the vitality of a constitutional democracy by this denial of information to the citizenry:

A popular Government, without popular information, or the means of acquiring it, is but a Prologue to a Farce or a Tragedy; or, perhaps both. Knowledge will forever govern ignorance: And a people who mean to be their own Governors, must arm themselves with the power which knowledge gives. ${ }^{320}$

Motions in limine were intended to promote fair trials for an accused in a criminal case. The criminal defendant who challenges or opposes government policy is entitled to the full benefit of constitutional protections and the right to be judged fairly by a jury. When the government uses the motion in limine to exclude an entire defense, the defendant's rights are seriously compromised, and the popular participation of the people in a constitutional democracy is substantially reduced. To guarantee those rights and to further the interest of an informed citizenry, the judiciary must reassume its role as protector of fairness and due process by allowing the jury to carry out its own historic role. 
Heinonline -- 39 Stan. L. Rev. 1328 1986-1987 